\title{
Coherence of long-term stratospheric ozone vertical distribution time series used for the study of ozone recovery at a northern mid-latitude station
}

\author{
P. J. Nair ${ }^{1}$, S. Godin-Beekmann ${ }^{1}$, A. Pazmiño ${ }^{1}$, A. Hauchecorne ${ }^{1}$, G. Ancellet ${ }^{1}$, I. Petropavlovskikh ${ }^{2}$, L. E. Flynn ${ }^{3}$, and \\ L. Froidevaux ${ }^{4}$ \\ ${ }^{1}$ UPMC Université Paris 06, Université Versailles-Saint-Quentin, UMR 8190, LATMOS-IPSL, CNRS/INSU, Paris, France \\ ${ }^{2}$ Cooperative Institute for Research in Environmental Sciences, Boulder, Colorado, USA \\ ${ }^{3}$ National Oceanic and Atmospheric Administration, 5200 Auth Rd, Camp Springs, MD, USA \\ ${ }^{4}$ Jet Propulsion Laboratory, California Institute of Technology, Pasadena, California, USA
}

Received: 20 September 2010 - Published in Atmos. Chem. Phys. Discuss.: 22 November 2010

Revised: 23 May 2011 - Accepted: 24 May 2011 - Published: 27 May 2011

\begin{abstract}
The coherence of stratospheric ozone time series retrieved from various observational records is investigated at Haute-Provence Observatory $\left(\mathrm{OHP}-43.93^{\circ} \mathrm{N}, 5.71^{\circ} \mathrm{E}\right)$. The analysis is accomplished through the intercomparison of collocated ozone measurements of Light Detection and Ranging (lidar) with Solar Backscatter UltraViolet(/2) (SBUV(/2)), Stratospheric Aerosol and Gas Experiment II (SAGE II), Halogen Occultation Experiment (HALOE), Microwave Limb Sounder (MLS) on Upper Atmosphere Research Satellite (UARS) and Aura and Global Ozone Monitoring by Occultation of Stars (GOMOS) satellite observations as well as with in situ ozonesondes and ground-based Umkehr measurements performed at OHP. A detailed statistical study of the relative differences of ozone observations over the whole stratosphere is performed to detect any specific drift in the data. On average, all instruments show their best agreement with lidar at $20-40 \mathrm{~km}$, where deviations are within $\pm 5 \%$. Discrepancies are somewhat higher below 20 and above $40 \mathrm{~km}$. The agreement with SAGE II data is remarkable since average differences are within $\pm 1 \%$ at $17-$ $41 \mathrm{~km}$. In contrast, Umkehr data underestimate systematically the lidar measurements in the whole stratosphere with a near zero bias at $16-8 \mathrm{hPa}(\sim 30 \mathrm{~km})$. Drifts are estimated using simple linear regression for the data sets analysed in this study, from the monthly averaged difference time series. The derived values are less than $\pm 0.5 \% \mathrm{yr}^{-1}$ in the $20-40 \mathrm{~km}$ altitude range and most drifts are not significant at the $2 \sigma$ level. We also discuss the possibilities of extending the SAGE II and HALOE data with the GOMOS and Aura MLS data in
\end{abstract}

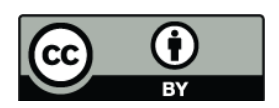

Correspondence to: P. J. Nair (gopalapi@aero.jussieu.fr) consideration with relative offsets and drifts since the combination of such data sets are likely to be used for the study of stratospheric ozone recovery in the future.

\section{Introduction}

The discovery of the Antarctic ozone hole by Farman et al. (1985) called for a tight monitoring of ozone and related trace species in the middle atmosphere. Though the mechanisms responsible for the decline of lower stratospheric polar ozone in winter/spring are relatively well understood (WMO, 2007), the ozone hole recovery over Antarctica is predicted to be at least half a century away, provided the current trends in ozone depleting substances are sustained (Newman et al., 2006). Ozone depletion in the mid-latitudes was also noted from observations (WMO, 1992). Significant decrease of upper stratospheric ozone in the northern mid-latitudes was observed in 1979-1995 by various measurements - (SPARC, 1998; WMO, 2007). For instance, Randel et al. (1999) found statistically significant trends of -7 to $-8 \% / d e c a d e$ at $40 \mathrm{~km}$ in $1979-1996$ from SAGE I/II (Stratospheric Aerosol and Gas Experiment I/II), SBUV(/2) (Solar Backscatter UltraViolet (/2)), Umkehr and ozonesonde measurements. A study by Li et al. (2002) confirmed the findings of Randel et al. (1999), and led to an estimate of about $-9 \% /$ decade in the upper stratosphere using SAGE I/II measurements in the same period. Logan et al. (1999) found $-10 \% /$ decade at $\sim 17 \mathrm{~km}$ by analysing sonde measurements. A similar trend $\left(\sim-0.8 \% \mathrm{yr}^{-1}\right)$, in the upper stratosphere $(\sim 40 \mathrm{~km})$, was also estimated by Newchurch et al. (2000) from SAGE I/II, SBUV(/2) and

Published by Copernicus Publications on behalf of the European Geosciences Union. 
Umkehr measurements. Even if not similar in scale to the observed high latitude decrease (WMO, 2007), the reduction of stratospheric ozone in the densely populated northern mid-latitudes is a serious concern.

Recent trend evaluation of stratospheric ozone deduced from various observations shows relatively constant ozone levels from 1996 onwards (Reinsel et al., 2002; WMO, 2007). This change in trend has been attributed to the levelling off of anthropogenic halogen abundances in the upper stratosphere from the mid-1990s (WMO, 2007). On the contrary, in the lower stratosphere the atmospheric dynamics has an influence in the declination of ozone loss (Yang et al., 2006). Dhomse et al. (2006) reported the effects of residual circulation on the increase of northern hemispheric total ozone rather than the decrease in Equivalent Effective Stratospheric Chlorine. Statistical analyses using different measurements indicate a trend of -6 to $-7 \% /$ decade in the upper stratosphere in 1979-2000 and a turnaround afterwards (e.g. Newchurch et al., 2003; Steinbrecht et al., 2006) in the northern mid-latitudes. Similar trends were also reported for some ground-based measurements. For instance, the analysis over Tsukuba showed a significant trend of $-6.0 \pm 0.5 \% /$ decade at $30-40 \mathrm{~km}$ from lidar and SAGE II observations for the period 1988-1997 and a statistically insignificant trend of $-0.8 \pm 1.1 \% /$ decade after 1998 (Tatarov et al., 2009). Further, the Umkehr measurements at Belsk estimated a trend of 3 to 5\%/decade in 1996-2007 (Krzyścin et al., 2009). The study by Jones et al. (2009) also revealed a trend of $-7.2 \pm 0.9 \% /$ decade in 1979-1997 and an insignificant trend of $1.4 \pm 2.3 \% /$ decade in $1997-2008$ at $35-45 \mathrm{~km}$ from several satellite measurements. The levelling off of ozone in the last decade reported by the above-said works is also confirmed by Steinbrecht et al. (2009), who utilised a series of satellite and ground-based observations for their analysis. These results underline the importance of continuous surveillance of stratospheric ozone in the northern midlatitudes.

Several ground-based instruments have been employed globally for constant monitoring of stratospheric ozone after the discovery of the Antarctic ozone hole. The Network for the Detection of Atmospheric Composition Change (NDACC) (initially termed as Network for the Detection of Stratospheric Changes - NDSC), a consortium of groundbased instruments, was established in 1991 to survey stratospheric composition change. The Haute-Provence Observatory $\left(\mathrm{OHP}-43.93^{\circ} \mathrm{N}, 5.71^{\circ} \mathrm{E}\right)$ is one of the northern midlatitude stations, which began geophysical observations in the 1970s and ozone measurements since 1983. Measurements using a Dobson spectrometer, ozonesondes, a stratospheric ozone lidar and an ultraviolet-visible (UV-Vis) SAOZ (Système d'Analyse par Observation Zénithale) spectrometer were initiated at OHP in 1983, 1984, 1985 and 1992 respectively, to observe both total column and vertical distribution of ozone. The OHP lidar measures the ozone vertical distribution and is the first of its kind selected under NDACC.
The objective of this study is to evaluate the coherence of ground-based and satellite measurements of the ozone vertical distribution above OHP to envisage the diagnosis of ozone recovery at northern mid-latitudes. It is achieved through the intercomparison of collocated ozone profiles from various instruments. We use lidar, Umkehr, ozonesondes, SBUV(/2), SAGE II and Halogen Occultation Experiment (HALOE) observations in this study as long-term data sets. Some of the shorter data sets such as Microwave Limb Sounder (MLS) on Upper Atmosphere Research Satellite (UARS) and Aura and Global Ozone Monitoring by Occultation of Stars (GOMOS) are also considered. The MLS measures ozone continuously and has a reasonable vertical resolution, while GOMOS performs occultation measurements and has a comparable vertical resolution to that of lidar and ozonesonde profiles.

The comparison of coincident ozone measurements helps to quantify uncertainties associated with each measurement system. We analyse the daily variations and the monthly averages of the relative differences of ozone over the observation period to understand how the measurements evolve with time. Analysing time series of coincident measurements allows one to reduce the effects of differences in temporal and spatial sampling, depending on the matching domain used. Simple linear regression can be applied to such data, whereby the resulting regression slopes provide more insights into accurate instrumental drift than that obtained from the individual ozone trends (e.g. Cunnold et al., 2000).

This article is arranged in the following way: introduction is followed by the description of ozone data sets and methodology of the analyses in Sects. 2 and 3, respectively. Section 4 describes the temporal evolution of relative differences, average biases and possible drifts in the ozone measurements. The final section of the paper presents conclusions of this study.

\section{Ozone measurements}

\subsection{Ground-based}

\subsubsection{Light detection and ranging}

The ozone lidar measurements are performed according to the Differential Absorption lidar (DIAL) technique, which requires the emission of two laser wavelengths with different ozone absorption cross sections. In the case of the OHP lidar, the absorbed radiation is emitted by a Xenon Chloride excimer laser at $308 \mathrm{~nm}$ and the reference line (non-absorbed wavelength) is provided by the third harmonic of a Nd:YAG laser at $355 \mathrm{~nm}$. The ozone vertical profile in number density is retrieved from the difference in slope of the logarithm of both lidar signals (Godin et al., 1999; Godin-Beekmann et al., 2003). Under high aerosol loading conditions, aerosols at the volcanic cloud altitude perturb the ozone profile 
locally. In order to solve this problem, two additional wavelengths are detected simultaneously, corresponding to the first Stokes vibrational Raman scattering by atmospheric nitrogen of the laser beams. These wavelengths allow an ozone profile to be obtained, which is much less perturbed by the presence of the volcanic aerosols (McGee et al., 1993).

After initial implementation of the lidar at OHP in 1985, systematic DIAL ozone measurements began in 1986 with a relatively simple lidar system that included only 2 electronic acquisition channels. In 1993, the instrumental setup was completely modified to enable measurements in the presence of volcanic aerosols and to improve the measurement capability of the lidar in terms of temporal resolution and accuracy (Godin-Beekmann et al., 2003). The observational capacity of the station was also increased during this period. The average number of measurements per year increased from $\sim 40$ in 1986-1993 to $\sim 110$ from 1994 onwards, with a peak of 190 in 1997 . The altitude range of each lidar profile is variable, due to the possible presence of clouds (or volcanic aerosols in the earlier period) in the lower stratosphere and variable signal to noise ratio in the upper stratosphere. In our case, the profiles are cut when $80 \%$ statistical error is reached. On average, ozone lidar measurements range from 26 to $43 \mathrm{~km}$ in $1985-1993$ and from 12 to $45 \mathrm{~km}$ in 1994-2009.

Lidar measurements are performed during the night under clear sky conditions. The accuracy depends on the duration of the measurement and the vertical resolution chosen to process the data. The typical duration of an ozone measurement in the whole stratosphere with the present DIAL system at $\mathrm{OHP}$ is $4 \mathrm{~h}$. The vertical resolution ranges from $0.5 \mathrm{~km}$ at $20 \mathrm{~km}$ to about $2 \mathrm{~km}$ at $30 \mathrm{~km}$, and it increases to $\sim 4.5 \mathrm{~km}$ at $45 \mathrm{~km}$. The average accuracy ranges from $\sim 5 \%$ below $20 \mathrm{~km}$ to more than $10 \%$ above $45 \mathrm{~km}$ and the best accuracy of $3 \%$ occurs in the $20-45 \mathrm{~km}$ altitude range. Further details about the instrument can be found in Godin-Beekmann et al. (2003).

Accuracy of the lidar ozone measurement depends partly on the accuracy of ozone absorption cross sections, which in turn depends on atmospheric temperature. The OHP lidar ozone profiles archived at NDACC use temperature profiles computed from nearby radiosonde data in the lower stratosphere and the COSPAR International Reference Atmosphere 1985 (CIRA-85) climatology in the upper stratosphere (Godin-Beekmann et al., 2003). Since this climatology has a warm bias of 5-10 K in the stratosphere (SPARC, 2002), in this work we use the National Center for Environmental Prediction (NCEP) temperature and pressure data to compute the ozone cross section. These data are also used for both the conversion of ozone number densities to ozone partial columns and geometric altitude to pressure vertical scale. The relative difference in the retrieved ozone using the old (radiosonde and CIRA) and the new (NCEP) data is within $\pm 0.5 \%$, due to the difference in temperature $( \pm 1.2 \%)$ used for the old and new retrievals.
Lidar ozone is taken as the reference to compare with other observations as it provides stable measurements since 1986 with an average of 15 measurements per month after 1994. It also yields more collocated profiles with other data sets. Since the DIAL technique is self calibrated, the experiment does not have problems with changing calibration constant. Nevertheless, there are some factors that can slightly affect the lidar ozone retrieval, like the temperature dependence and the interference of stratospheric aerosol or other minor compounds. A study by Godin-Beekmann et al. (2003) shows that the contribution of these factors on the ozone trends is negligibly small. Additionally, among the longterm data sets, Umkehr and $\operatorname{SBUV}(/ 2)$ have lower vertical resolution and hence, the comparison of others with these instruments may remove some of the fine vertical features. Further, SAGE II and HALOE terminate their operation in 2005 and SAGE II ozone measurements degrade after 2000. Hence, among the long-term data sets, lidar is most suitable to compare with other long and short term observations.

\subsubsection{Ozonesondes}

Ozonesondes are characterised by a higher vertical resolution $(\sim 0.2 \mathrm{~km})$ than other measurements. At OHP, the ozone soundings were performed by Brewer-Mast sondes from 1985 to 1991 and afterwards by Electrochemical Concentration Cell (ECC) sondes, using the standard $1 \%$ buffered potassium iodide $(\mathrm{KI})$ cathode sensor solution as given by Komhyr (1969). In order to avoid inhomogeneity due to different ozone sensors we consider ozone observations from ECC sondes in 1991-2009 only. During the period the ozonesonde system at OHP has experienced a number of changes. For instance, ECC sondes manufactured by Science Pump Corporation (SPC-5A) were flown from January 1991 to March 1997. In March 1997, they were replaced by $1 Z$ series ECC sondes of Environmental Science Corporation (ENSCI) and are still in use. The acquisition system was also changed, for which the ECC sondes coupled with the Vaisala RS80 radiosondes by a TMAX interface were used until 2007. Ozone values were derived using the concept designed by KFA Julich (Ancellet and Beekmann, 1997) in 1995-2003 and the "strato" program (Vömel, 2002) in 20042007. Since 2007 Modem M2K2DC radiosondes coupled to ENSCI-Z ECC sondes by OZAMP Modem interface board have been used.

Recent studies have analysed the differences in ozone measurements from various types of sondes (Johnson et al., 2002; Smit et al., 2007; Deshler et al., 2008; Stübi et al., 2008). These studies report that ENSCI-Z ECC sondes overestimate ozone by $\sim 5 \%$ below $20 \mathrm{~km}$ and $5-10 \%$ above $20 \mathrm{~km}$ as compared to SPC-6A ECC sondes, when both operate with $1 \% \mathrm{KI}$ full buffer cathode solution. The decrease in pump efficiency at reduced pressures is corrected by a pump correction factor that increases with the decrease in air pressure. It affects predominantly the upper part of the ozone 
profile. In the middle stratosphere, the measured uncertainties are larger due to inconsistent pump efficiency and increase in cathode sensor solution concentration by evaporation. In general, sonde profiles are good up to $\sim 32 \mathrm{~km}$ with an accuracy of about $\pm 5-10 \%$ (Smit et al., 2007).

The correction factor (the ratio of the total ozone from column measuring instrument located at the same site to the total ozone integrated up to the burst level of ozonesonde measurements), a quality control parameter, is used to normalise the sonde profiles. At OHP, Dobson spectrophotometer is used to calculate the normalisation factor until 2007 and SAOZ afterwards. The residual ozone column is computed from the measured ozone at the last altitude and the relative ozone altitude variation based on a monthly ozone climatology derived from the stratospheric ozone lidar data from 22 to $35 \mathrm{~km}$ and MAP85 above $35 \mathrm{~km}$ (Ancellet and Beekmann, 1997). In this study, the correction factor has been used to screen and correct the ozone profiles (see Sect. 3.1).

\subsubsection{Umkehr}

Umkehr observations at OHP are performed using an automated Dobson spectrophotometer, measuring the ratio of transmitted zenith sky radiance at a wavelength pair in the ultraviolet ( 311.5 and $332.5 \mathrm{~nm}$ ), with the former strongly and the latter weakly absorbed by ozone. The general procedure of the Umkehr ozone retrieval is that the ozone measurements are partitioned into 10 Umkehr layers which are divided into equal log pressure vertical intervals between $\sim 1013$ and $\sim 1 \mathrm{hPa}$. It is assumed that the pressure at the top of an Umkehr layer is half of the pressure at the adjacent bottom layer. However, layer 1 is a double layer containing information of layers 0 and $1(1013-250 \mathrm{hPa})$. Based on averaging kernels (AKs), Umkehr has independent ozone information in layers $4-8$ while other layers are interdependent and are combined to $4^{-}$(layers $0,1,2,3$ ) and $8^{+}$(layer 8 and above) to provide useful information (see Table 2 of Petropavlovskikh et al., 2005a). We use ozone profiles retrieved with the UMK04 algorithm (Petropavlovskikh et al., $2005 \mathrm{~b}$ ). The vertical resolution of UMK04 is $\sim 10 \mathrm{~km}$ and the estimated accuracy is better than $10 \%$ for layers 4-8 (64$2 \mathrm{hPa}$ (WMO, 2007). The UMK04 algorithm was designed to produce ozone profiles optimised for monthly averaged long-term trends. Although, the Umkehr ozone profiles tend to have biases relative to other measurements, the data are useful for studies of the long-term ozone evolution.

\subsection{Space-borne}

\subsubsection{Solar backscatter ultraviolet $(/ 2)$}

The first generation of $\operatorname{SBUV}(/ 2)$ instruments was launched on the NASA (National Aeronautics and Space Administration) NIMBUS-7 satellite and the second on the NOAA (National Oceanic and Atmospheric Administration) -9, 11, 14,
$16,17,18$ and 19 satellites. The instruments make use of the nadir viewing technique for measuring ozone profiles from the backscattered UV radiation $(250-340 \mathrm{~nm})$. The ozone values are derived from the ratio of the observed backscattered spectral radiance to the incoming solar spectral irradiance (Bhartia et al., 1996). The instruments provide a continuous record of stratospheric ozone measurements from November 1978 to December 2007. The vertical resolution of version (V) 8 data is $6-8 \mathrm{~km}$ and the horizontal resolution is $200 \mathrm{~km}$ (Bhartia et al., 2004). The latitudinal coverage of the measurements is $80^{\circ} \mathrm{S}-80^{\circ} \mathrm{N}$ and the long-term calibration accuracy is $\sim 3 \%$ (DeLand et al., 2004). SBUV(/2) measures about 35000 profiles per month (McLinden et al., 2009). We use V 8 ozone column profiles from NIMBUS-7, NOAA-9, 11, 16 and 17 in 1985-2007 for this study (Flynn et al., 2009).

\subsubsection{Stratospheric aerosol and gas experiment II}

SAGE II, an instrument aboard Earth Radiation Budget Satellite (ERBS), has provided long-term observations of ozone from 1984 to 2005 . It uses the solar occultation technique for measuring limb transmittance in seven channels between 385 and $1020 \mathrm{~nm}$ during each sunrise and sunset, and an inversion using the onion-peeling approach (Wang et al., 2002). It observes up to 15 sunrise and 15 sunset events each day, and the consecutive measurements are separated by $24.5^{\circ}$ in longitude and slightly in latitude. The spatial coverage ranges from approximately $80^{\circ} \mathrm{S}$ to $80^{\circ} \mathrm{N}$ and sampling takes about a month to progress from one latitudinal extreme to the other. The vertical range of the ozone profiles is $10-50 \mathrm{~km}$ with a vertical resolution of $\sim 1 \mathrm{~km}$ and a horizontal resolution of $200 \mathrm{~km}$. The ozone measurements have an accuracy of $\sim 5 \%$ at $20-45 \mathrm{~km}$ and $5-10 \%$ at $15-20 \mathrm{~km}$. The ozone number density profiles retrieved in geometric altitudes and processed by the V 6.2 algorithm (Wang et al., 2006) for the period 1985-2005 are used in this work.

\subsubsection{Halogen occultation experiment}

HALOE on the UARS was put into orbit in September 1991, and operated for 15 years, until 2005 . This is another solar occultation instrument and it measures limb transmittance from the $9.6 \mu \mathrm{m}$ ozone band. The ozone profiles are derived from the ratio of solar intensity measured as a function of tangent height to the exo-atmospheric signal and are inverted by applying the onion-peeling procedure. It performs approximately 30 observations per day from both sunrise and sunset in small latitude bands separated by $24^{\circ}$ in longitude. The latitudinal coverage of the measurements is $80^{\circ} \mathrm{S}-80^{\circ} \mathrm{N}$ over the course of one year. The vertical range of the ozone profiles is $15-60 \mathrm{~km}$ with a vertical resolution of $\sim 2 \mathrm{~km}$ and a horizontal resolution of $500 \mathrm{~km}$. Accuracy of the measured profiles is about $10 \%$ at $30-64 \mathrm{~km}$ and $\sim 30 \%$ at $15 \mathrm{~km}$ (Brühl et al., 1996). Further details about the instrument can 
be found in Russell et al. (1993). Ozone volume mixing ratio (VMR) profiles from V 19 for 1991-2005 are used for the comparison.

\subsubsection{Microwave limb sounder}

MLS was launched on UARS in 1991 and its successor aboard Aura in 2004. These instruments measure thermal emissions from rotational lines of the measured species through the limb of the atmosphere. The $57^{\circ}$ inclination of the UARS orbit allowed MLS to observe from $34^{\circ}$ on one side of the equator to $80^{\circ}$ on the other. UARS performs a $180^{\circ}$ yaw manoeuvre at $\sim 36$ day intervals allowing it to switch the viewing geometry between northern and southern high latitudes. Because of instrumental deterioration, the number of operational days per year decreased gradually from late 1991 to 1993 . It reached about $50 \%$ of the initial number in 1994 and became very small from 1995 onwards, largely because of spacecraft power-sharing constraints. The profiles retrieved from $205 \mathrm{GHz}$ have a vertical range of $15-60 \mathrm{~km}$ with a resolution of $\sim 3-4 \mathrm{~km}$, and the horizontal (along-track) resolution is $300 \mathrm{~km}$. The estimated accuracy of a single profile is $6 \%$ at $21-60 \mathrm{~km}$ and $15 \%$ at $16-20 \mathrm{~km}$ (Livesey et al., 2003). Its successor, Aura MLS, has a better spatial coverage and horizontal and vertical resolutions. The latitudinal coverage of the measurements is $82^{\circ} \mathrm{S}-82^{\circ} \mathrm{N}$ on a daily basis and it provides about 3500 profiles per day. Ozone measurements retrieved from $240 \mathrm{GHz}$ have a vertical range of $12-73 \mathrm{~km}$ with a vertical resolution of $2-3 \mathrm{~km}$, below $65 \mathrm{~km}$. The horizontal resolution is $\sim 200 \mathrm{~km}$ and the accuracy is about $5-10 \%$ between 16 and $60 \mathrm{~km}$ (Froidevaux et al., 2008). The ozone VMRs of UARS MLS V 5 from 1991-1999 and Aura MLS V 2.2 from 2004-2009 are used for the analysis.

\subsubsection{Global ozone monitoring by occultation of stars}

GOMOS on board the Environmental Satellite (ENVISAT) employs the stellar occultation technique for measuring ozone in UV, visible and near infrared wavelength ranges $(250-950 \mathrm{~nm})$. Measurements are retrieved using the Tikhonov regularisation method (Kyrölä et al., 2010). The payload was placed in orbit in 2002 and is observing the atmosphere with a global coverage. It executes about 100000 occultations per year. The altitude range of dark limb profiles is $15-100 \mathrm{~km}$ with a vertical resolution ranging from $2 \mathrm{~km}$ below $30 \mathrm{~km}$ to $3 \mathrm{~km}$ above $40 \mathrm{~km}$, and a horizontal resolution of $300 \mathrm{~km}$. The estimated accuracy of the ozone profiles varies with the visual magnitude and the temperature of the star being focused at. It is less than $5 \%$ at $25-60 \mathrm{~km}$ for a star with temperature higher than $10000 \mathrm{~K}$ and visual magnitude up to 2. Below $25 \mathrm{~km}$ the accuracy is independent of star temperature and is 3 and $10 \%$ for stars with visual magnitudes 0 and 2 respectively. Ozone profiles retrieved on dark limb are of better quality than on bright limb because of the perturbations from background light (Hauchecorne et al., 2010). We use dark limb profiles retrieved with the V 5 algorithm from 2002 to 2009 for this study.

\section{Methodology}

\subsection{Selection criteria}

As each instrument uses a different observation technique and has a different viewing geometry, the selection criteria for the comparisons differ in accordance with the measurement characteristics in order to achieve a reasonable sampling at OHP. Lidar observations below $25 \mathrm{~km}$ are almost excluded for the period 1991-1993 because of aerosol contamination due to Mount Pinatubo volcanic eruption (Guirlet et al., 2000). Umkehr measurements are highly sensitive to aerosols and thus the data from June 1991 to June 1993, affected by the Mount Pinatubo eruption, are omitted from the analysis as suggested by SPARC (1998). Since SAGE II measurements are also very much affected by aerosol loading, the filters proposed in SPARC (1998) are adopted.

Product error flags are used as another screening criterion considered in our study. Ozone profiles with flag 0 for GOMOS (from the meta data) and $0,10,100$ and 110 for $\operatorname{SBUV}(/ 2)$ (recommended in V 8 data quality) are selected for our analysis. The ozonesonde profiles with a correction factor between 0.8 and 1.2 (SPARC, 1998) are considered here (the profiles are later multiplied by the respective correction factors). Aura MLS profiles are screened as per the criteria given by Froidevaux et al. (2008). For example, ozone profiles with convergence $<1.8$ and quality $>0.4$, and temperature and geopotential height fields with convergence $<1.2$ and quality $>0.6$ are considered. Negative values of ozone are excluded from the analysis for all measurement techniques.

The coincidences are determined with the spatial restriction of $\pm 2.5^{\circ}$ latitude and $\pm 5^{\circ}$ longitude, in general, and the temporal criterion of $\pm 12 \mathrm{~h}$. Occultation measurements provide comparatively less sampling, so the spatial criterion is relaxed for SAGE II, HALOE and GOMOS measurements. Since the zonal variation of ozone is less compared to the meridional one, the longitudinal restriction is relaxed in order to obtain a reasonable number of collocated profiles for better statistics. The spatial criterion is tightened for Aura MLS as it provides the largest number of collocated measurements with the lidar within the prescribed area. Also, satellite measurements yield more than one coincidence a day. In that case, the one closest in latitude and time is used. The spatial and temporal criteria and the number of matching events obtained for each data set with lidar are listed in Table 1 . Comparison periods depend on the time overlap between the measurements from lidar and other instruments. Since SAGE II and HALOE observe during sunrise and sunset, the impacts of diurnal ozone variations cannot be completely 
Table 1. Statistics of the comparison study: selection criteria in latitude (Lat) and longitude (Lon) applied for the satellite measurements with respect to $\mathrm{OHP}\left(43.93^{\circ} \mathrm{N}, 5.71^{\circ} \mathrm{E}\right)$, time period (Year) and the maximum number of coincident profiles obtained seasonally [Winter (January, February, and March - JFM), Spring (April, May, and June - AMJ), Summer (July, August, and September - JAS), and Autumn (October, November, and December - OND)] and over the collocative periods $(N)$ with the time difference of $\pm 12 \mathrm{~h}$.

\begin{tabular}{lrrlrrrrr}
\hline Instrument & $\begin{array}{r}\Delta \text { Lat } \\
(\mathrm{N})\end{array}$ & $\begin{array}{r}\Delta \text { Lon } \\
(\mathrm{E})\end{array}$ & $\begin{array}{l}\text { Period } \\
(\text { Year })\end{array}$ & $\begin{array}{r}\text { Winter } \\
(\mathrm{JFM})\end{array}$ & $\begin{array}{r}\text { Spring } \\
(\text { AMJ })\end{array}$ & $\begin{array}{r}\text { Summer } \\
(\mathrm{JAS})\end{array}$ & $\begin{array}{r}\text { Autumn } \\
(\text { OND })\end{array}$ & $\begin{array}{r}\text { Total } \\
N\end{array}$ \\
\hline SBUV(/2) & \pm 2.5 & \pm 5 & $1985-2007$ & 227 & 201 & 225 & 173 & 826 \\
SAGE II & \pm 5 & \pm 10 & $1985-2005$ & 88 & 20 & 20 & 85 & 213 \\
HALOE & \pm 5 & \pm 10 & $1991-2005$ & 69 & 4 & 11 & 62 & 146 \\
UARS MLS & \pm 2.5 & \pm 5 & $1991-1999$ & 53 & 26 & 39 & 32 & 150 \\
GOMOS & \pm 2.5 & \pm 10 & $2002-2009$ & 46 & 31 & 28 & 38 & 143 \\
Aura MLS & \pm 2 & \pm 2 & $2004-2009$ & 55 & 42 & 45 & 49 & 191 \\
ozonesondes & & & $1991-2009$ & 102 & 91 & 89 & 65 & 347 \\
Umkehr & & & $1985-2007$ & 204 & 177 & 203 & 178 & 762 \\
\hline
\end{tabular}

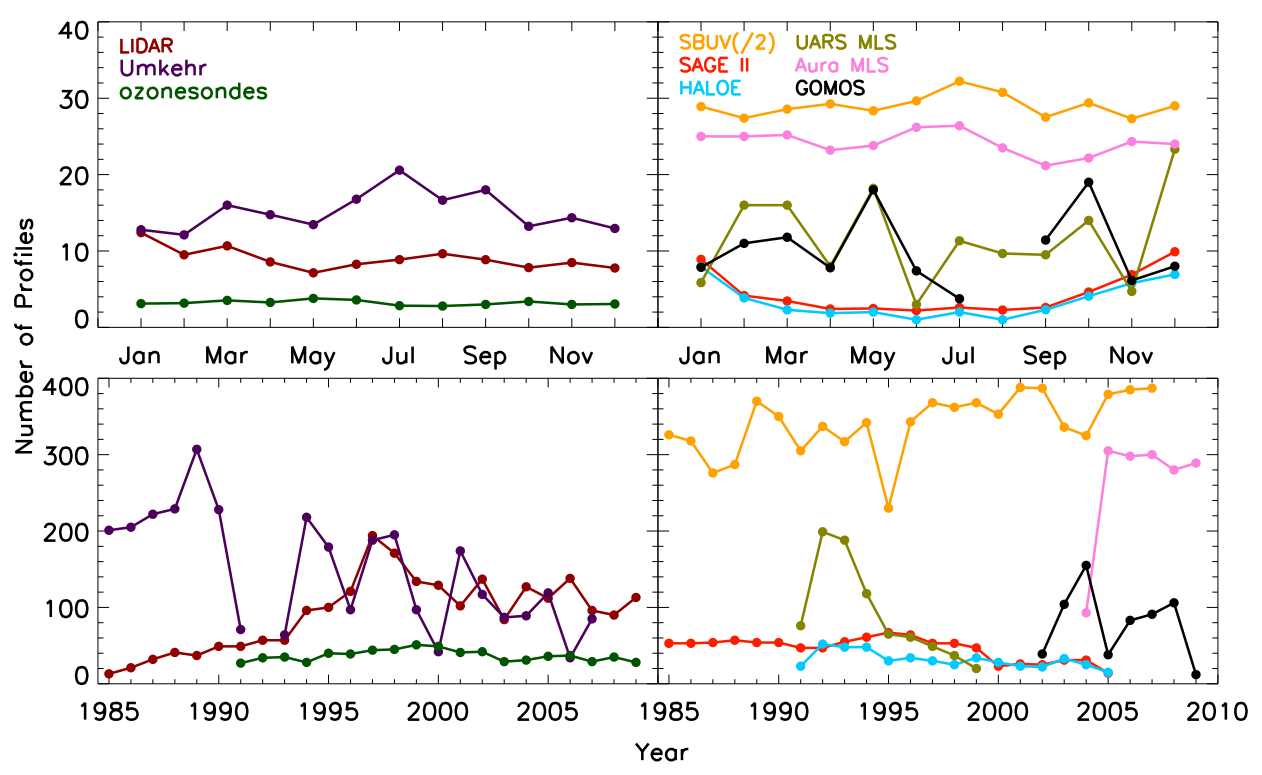

Fig. 1. Average number of observations in each month over the respective period (top panel) and the total number of observations in each year (bottom panel) of various data sets. Left: ground-based measurements at OHP. Right: satellite observations extracted around OHP.

ruled out. However, the diurnal effects become significant only above about $1 \mathrm{hPa}(\sim 48 \mathrm{~km})$, (Nazaryan et al., 2007; Boyd et al., 2007), which is beyond the range considered in our study. Therefore, this effect is not taken into account for our analysis.

The number of observations in each month averaged over the period and the total number of observations in each year retrieved from various data sets (satellite measurements are extracted around the OHP station using the spatial criteria given in Table 1) are shown in Fig. 1. As is evident in the figure (top panel), the number of ozonesonde measurements does not vary seasonally whereas it does for other data sets. The maximum number of observations for lidar and Umkehr are found in winter and summer respectively. Among the satellite observations, SAGE II and HALOE provide comparatively fewer observations, with a maximum in winter and autumn. From the bottom panel it is clear that the number of lidar measurements increased from 1994 onwards; the lidar provided an average of about 110 measurements per year with a maximum of 190 in 1997. Umkehr provided more profiles at the beginning of the observation period, with a maximum of 320 in 1989. Since ozonesondes are launched usually once a week, the number of measurements are fewer and are about 50 per year on average. SAGE II observations show degradation after 1999, while HALOE provided almost constant measurements throughout the period (for e.g. Remsberg et al., 2009), with a slightly higher number in 1992-1994. SBUV(/2) and Aura MLS have more profiles throughout the 


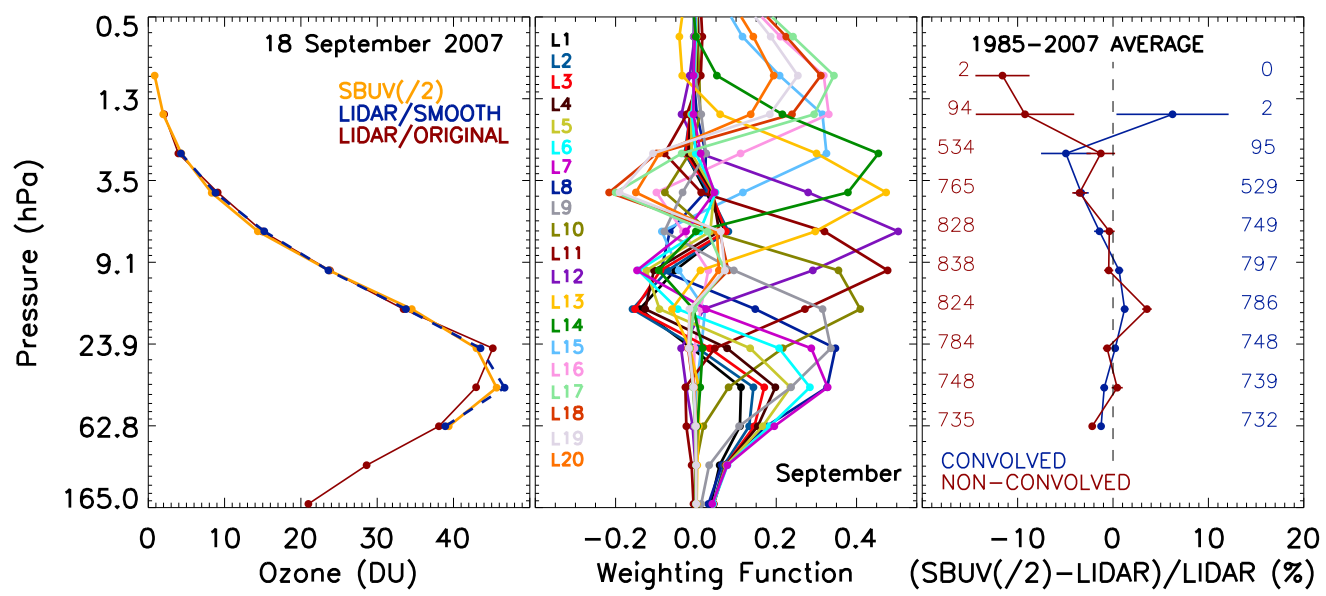

Fig. 2. Left: comparison of lidar measurements, both original and convolved, with SBUV(/2) on 18 September 2007 at OHP. Middle: SBUV(/2) averaging kernels used for convolving lidar data. Right: average relative deviation over the period (1985-2007) between SBUV(/2) and lidar (with and without convolution using averaging kernels and a priori) coincident profiles. The number of analysed profiles with and without convolution are also provided in respective colours. The dashed line represents $0 \%$ and the error bars represent twice the standard error.

period. As already mentioned, a gradual decrease in the number of observations with time is found for UARS MLS.

\subsection{Data conversion and analysis}

The altitude grid of the retrieval varies for each instrument and hence the analyses differ in accordance with the data characteristics. The lidar ozone retrievals are in number density $\left(\mathrm{cm}^{-3}\right)$ on geometric height $(\mathrm{km})$ with a sampling resolution of $150 \mathrm{~m}$. Except for SBUV(/2) and Umkehr ozone column observations, other measurement techniques are generally converted to ozone number density.

Ozonesonde measurements in partial pressure $(\mathrm{mPa})$ are converted to number density, using temperature data from sonde measurements, and are compared to that of lidar by interpolating both data sets onto $150 \mathrm{~m}$ altitude grids. Since Umkehr measurements are in Dobson Unit (DU), the lidar profile is converted to DU and partial ozone columns are calculated above the pressure levels from NCEP data (as desribed in Sect. 2.1.1.) corresponding to lidar altitudes. The resulting partial columns are interpolated to 61 Umkehr pressure levels and the consecutive values are subtracted to obtain the ozone profile in quarter Umkehr layers. The lidar ozone values at pressure levels within the standard Umkehr layers (Petropavlovskikh et al., 2005b) are then added to get ozone column at standard Umkehr layers. The smoothing of lidar profiles with Umkehr AKs and a priori was tested (Griesfeller et al., 2011); this did not make a significant difference to the annual average. Nonetheless, some differences are observed in seasonally averaged data especially in winter and autumn with maximum difference of 3.6 and $2.6 \%$ respectively. In this study we compared the lidar data without AK smoothing.
The vertical resolutions of the occultation measurements (SAGE II, HALOE and GOMOS) are similar to that of the lidar. Hence, the satellite and lidar profiles are interpolated to $1 \mathrm{~km}$ grid, the standard vertical resolution of the occultation measurements to get the same vertical window for comparison, HALOE ozone values measured in VMRs are converted to number density by using temperature and pressure from HALOE data. The ozone VMR profiles from MLS measurements are converted to number density using the corresponding MLS temperature and pressure. Geopotential heights are taken as the geometric altitudes for MLS as the difference between them is very small in the studied altitudes $(\sim 0.04$ and $0.33 \mathrm{~km}$ at 15 and $45 \mathrm{~km}$ respectively). So it hardly affects the derived ozone values even in steep gradient regions. Comparison with both MLS sensors is performed on their original lower resolution altitude grids. For that, the higher resolution lidar profile is integrated (trapezoidal integration) vertically within $\pm 1.5 \mathrm{~km}$ altitude band with respect to the MLS altitudes. Then both data are interpolated onto an average altitude grid calculated for the periods of MLS data. Also, comparison at specific altitudes (see Sect. 4.1) is performed by interpolating the data to the limits of the altitude ranges, referred in Fig. 6, if they are not available.

Regarding SBUV(/2), a priori data are provided in DU. Hence comparison with lidar is performed by convolving the lidar data with SBUV(/2) AKs. The lidar profile is first converted to DU and partial columns are added above each pressure level with respect to lidar altitudes. The resulting values are interpolated to the pressure levels of the $\operatorname{SBUV}(/ 2)$ ozone AKs, and the adjacent layers are then subtracted to obtain partial ozone column in each layer. The lidar profiles are convolved with the AKs of $\operatorname{SBUV}(/ 2)$ using the following 
Table 2. Statistics derived from coincident measurements of lidar ozone at OHP with various observations. Number of matching events $(N)$, mean $(M)$, standard deviation $(\sigma)$, and standard error $\left(\sigma_{N}\right)$ calculated from the time series of daily variations $(\%)$ for the selected altitudes are noted. Umkehr and $\operatorname{SBUV}(/ 2)$ are given on pressure levels. $M, \sigma$ and $\sigma_{N}$ are given in $\% . \sigma_{N}$ is computed as $\sigma / \sqrt{N}$.

\begin{tabular}{|c|c|c|c|c|c|c|c|c|c|c|c|c|c|c|c|c|c|c|c|c|c|c|c|c|}
\hline \multirow[t]{2}{*}{ Instrument } & $N$ & $M$ & $\sigma$ & $\sigma_{N}$ & $N$ & $M$ & $\sigma$ & $\sigma_{N}$ & $N$ & $M$ & $\sigma$ & $\sigma_{N}$ & $N$ & $M$ & $\sigma$ & $\sigma_{N}$ & $N$ & $M$ & $\sigma$ & $\sigma_{N}$ & $N$ & $M$ & $\sigma$ & $\sigma_{N}$ \\
\hline & \multicolumn{4}{|c|}{$16-20 \mathrm{~km}$} & \multicolumn{4}{|c|}{$19-23 \mathrm{~km}$} & \multicolumn{4}{|c|}{$23-27 \mathrm{~km}$} & \multicolumn{4}{|c|}{$28-32 \mathrm{~km}$} & \multicolumn{4}{|c|}{$33-37 \mathrm{~km}$} & \multicolumn{4}{|c|}{$38-42 \mathrm{~km}$} \\
\hline SAGE II & 146 & 0.01 & 15.53 & 1.29 & 155 & 0.68 & 9.41 & 0.76 & 170 & 0.66 & 6.73 & 0.52 & 191 & 0.23 & 10.01 & 0.72 & 206 & 1.39 & 11.81 & 0.82 & 178 & -0.32 & 15.06 & 1.13 \\
\hline HALOE & 123 & -2.21 & 17.40 & 1.57 & 125 & -2.91 & 8.06 & 0.72 & 126 & -2.97 & 6.93 & 0.62 & 134 & -2.64 & 8.21 & 0.71 & 142 & 1.01 & 8.64 & 0.73 & 134 & -0.25 & 11.37 & 0.98 \\
\hline UARS MLS & 28 & 14.77 & 24.62 & 4.65 & 70 & 7.95 & 13.40 & 1.60 & 79 & 5.67 & 8.22 & 0.92 & 89 & 4.16 & 7.83 & 0.83 & 123 & 4.55 & 10.98 & 0.99 & 74 & 2.03 & 17.47 & 2.03 \\
\hline GOMOS & 65 & -2.13 & 25.29 & 3.14 & 121 & -4.12 & 9.46 & 0.86 & 143 & -2.80 & 6.57 & 0.55 & 143 & -1.23 & 6.12 & 0.52 & 142 & -2.86 & 5.95 & 0.50 & 129 & -1.53 & 13.00 & 1.15 \\
\hline Aura MLS & 94 & -3.84 & 10.97 & 1.13 & 189 & 3.05 & 7.47 & 0.54 & 190 & 1.26 & 3.62 & 0.26 & 189 & -0.99 & 4.62 & 0.34 & 180 & -0.44 & 5.57 & 0.41 & 148 & -7.45 & 8.06 & 0.92 \\
\hline \multirow[t]{2}{*}{ ozonesondes } & 321 & -5.42 & 11.48 & 0.64 & 320 & -2.49 & 7.05 & 0.39 & 307 & -0.42 & 5.69 & 0.32 & 239 & -0.70 & 7.36 & 0.48 & & & & & & & & \\
\hline & \multicolumn{4}{|c|}{$63.1-40 \mathrm{hPa}$} & \multicolumn{4}{|c|}{$40-25.1 \mathrm{hPa}$} & \multicolumn{4}{|c|}{$25.1-15.8 \mathrm{hPa}$} & \multicolumn{4}{|c|}{$15.8-10 \mathrm{hPa}$} & \multicolumn{4}{|c|}{$6.31-4 \mathrm{hPa}$} & \multicolumn{4}{|c|}{$4-2.51 \mathrm{hPa}$} \\
\hline \multirow[t]{3}{*}{$\operatorname{SBUV}(/ 2)$} & 732 & -1.21 & 9.47 & 0.35 & 739 & -0.90 & 5.3 & 0.20 & 748 & 0.21 & 5.22 & 0.20 & 786 & 1.27 & 5.28 & 0.20 & 749 & -2.10 & 6.12 & 0.24 & 95 & -4.16 & 7.56 & 0.35 \\
\hline & & & & & \multicolumn{4}{|c|}{$63-32 \mathrm{hPa}$} & \multicolumn{4}{|c|}{$32-16 \mathrm{hPa}$} & \multicolumn{4}{|c|}{$16-8 \mathrm{hPa}$} & \multicolumn{4}{|c|}{$8-4 \mathrm{hPa}$} & \multicolumn{4}{|c|}{$4-2 \mathrm{hPa}$} \\
\hline & & & & & 640 & -7.75 & 11.89 & 0.47 & 696 & -3.59 & 8.50 & 0.32 & 733 & 0.07 & 8.11 & 0.30 & 741 & -8.77 & 8.79 & 0.32 & 603 & -14.29 & 13.27 & 0.54 \\
\hline
\end{tabular}

equation:

$L_{\mathrm{S}}(i)=\sum_{i, j}\left[\frac{\mathbf{A K}(i, j) \times\left(L_{\mathrm{O}}(j)-A(j)\right)}{A(j)}\right] \times A(i)+A(i)$

where $L_{\mathrm{S}}=$ Smoothed lidar ozone in $i$-th pressure level, $L_{\mathrm{O}}=$ Lidar ozone in $j$-th pressure level, $\mathbf{A K}=$ averaging kernel matrix, and $A=\operatorname{SBUV}(/ 2)$ a priori in $i$ and $j$ pressure levels.

We also tested the comparison without convolving the lidar data with SBUV(/2) AKs. In that case, the lidar ozone number densities are converted to DU, and are added above the pressure levels corresponding to lidar altitudes. Then, they are interpolated to pressure levels of $\operatorname{SBUV}(/ 2)$ ozone column and then the consecutive partial columns are subtracted.

Figure 2 shows an example of the $\operatorname{SBUV}(/ 2)$ and lidar profile and the lidar profile convolved using SBUV(/2) ozone AKs for 18 September 2007 in the left panel and SBUV(/2) AKs in September above OHP in the middle panel. The right panel of the Fig. 2 shows the average relative difference over the period (1985-2007) between SBUV(/2) and lidar (convolved and non-convolved). The error bars represent twice the standard error. The total number of profiles over the period are also noted in the respective colours. As illustrated in the figure (left panel), the original lidar data differs from SBUV(/2) below $23.9 \mathrm{hPa}$, but the smoothing with $\mathrm{AK}$ reduces this difference. From the right panel, it is evident that the average relative difference of SBUV(/2) with the convolved lidar is more smoother than that with the nonconvolved lidar. The error bars below $2.51 \mathrm{hPa}$ are very small because of the large number of coincident profiles between the convolved and non-convolved lidar. The results are quite similar except at 2.51 and $1.58 \mathrm{hPa}$. This difference can be due to the low number of matching events with the convolved lidar, as in that case, the lidar data are selected when they reach the pressure levels where $\operatorname{SBUV}(/ 2)$ weighting functions are greater than 0.2 , which corresponds to an altitude of $\sim 45 \mathrm{~km}$, not reached by most lidar profiles, particularly prior to 1994.
The relative deviation of the collocated ozone profiles is calculated for each instrument represented by "Meas" as:

$\Delta \mathrm{O}_{3}(i, j)=\frac{\operatorname{Meas}(i, j)-\operatorname{lidar}(i, j)}{\operatorname{lidar}(i, j)} \times 100 \%$

where $i=$ coincident day, and $j=$ altitude or pressure.

We have also analysed the data for each season and the analysis takes Winter as January, February and March (JFM), Spring as April, May and June (AMJ), Summer as July, August and September (JAS), and Autumn as October, November and December (OND).

\section{Results and discussion}

\subsection{Time series of relative differences}

Relative differences are calculated for SAGE II, HALOE, ozonesondes, UARS MLS, Aura MLS and GOMOS at altitudes 18, 21, 25, 30, 35 and $40 \mathrm{~km}$ by averaging ozone over a range of $\pm 2 \mathrm{~km}$ in order to provide relatively smooth time series of ozone measurements and also to homogenise different data sets for the comparisons. The resulting values for the long-term data are presented in Figs. 3, 4 and 5, and for the short-term data in Fig. 6. An overview of the combined long and short-term satellite observations are given in Fig. 7. Monthly average results are shown with black dots and daily values are with grey dots in the background. The monthly average data show smaller differences than the daily ones and hence the analysis focuses on the former. In general, monthly deviations are larger if there is only one or a small number of collocated events. A detailed discussion of the salient features of each data set with respect to altitude is presented in the following sections and in Table 2.

\subsubsection{Long-term data sets}

Figure 3 (left panel) represents the comparison of SAGE II with lidar ozone in 1985-2005. The best agreement between the data sets is seen at $19-23$ and $23-27 \mathrm{~km}$, where monthly 


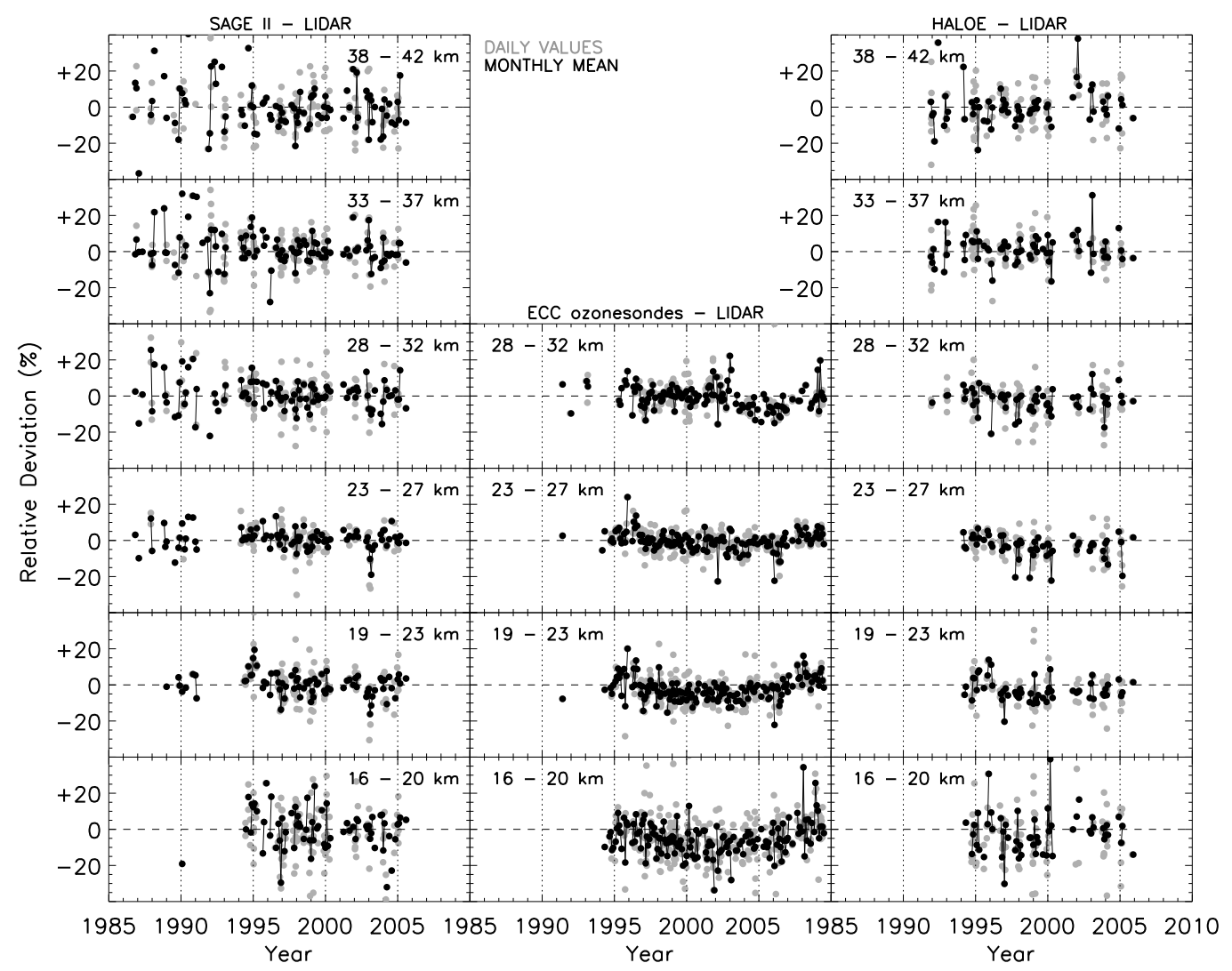

Fig. 3. Comparison of lidar ozone profiles coincident with SAGE II (left panel), ozonesondes (middle panel) and HALOE (right panel). The black solid circles represent the monthly mean of the relative differences and grey solid circles represent daily values. The dashed horizontal lines represent $0 \%$ and the dotted vertical lines represent year 1990, 1995, 2000, and 2005.

deviations are less than $\pm 5 \%$. At $28-32$ and $33-37 \mathrm{~km}$ the variations are within $\pm 10 \%$ and, at $16-20$ and $38-42 \mathrm{~km}$ they exceed $\pm 10 \%$. The differences are in general larger prior to 1994 because of the lower quality of lidar data and the fewer number of matching events.

Figure 3 (middle panel) displays the relative differences between ozonesondes and lidar data in 1991-2009. A good agreement of $\pm 5 \%$ is found at $19-23,23-27$ and $28-32 \mathrm{~km}$. All altitudes exhibit a similar behaviour in that the differences decrease until 1997 and stabilises afterwards up to 2006, and then starts to increase. This change in 1997 can be due to a relatively higher value of the correction factors in 1995-1997, which on multiplication with the ozone gives rise to high ozone from ozonesondes. Also, the positive bias found after 2007 coincides in part because of the change in ozone receiving system from Vaisala to Modem and in part due to the change in the instrument (from Dobson to SAOZ) used for normalising the sonde profiles, as described in Sect. 2.1.2. However, the Dobson and SAOZ total ozone column measurements, for the coincident days of sondes and lidar, shows an average difference of $2 \%$ in 2007-2009. Further differences originated from the changes in the systems and methods used for deriving the ozone are being investigated. These results pinpoint the need of a homogenised data for ozone trend evaluation.

In terms of altitudes, the ozonesonde-lidar comparison shows slight negative biases at $16-20$ and $19-23 \mathrm{~km}$ compared to other altitudes. The average lidar ozone is about $4.6 \%$ larger than that of sondes in the $16-23 \mathrm{~km}$ range, which is similar to the results of Godin-Beekmann et al. (2003), who compared average lidar ozone concentration to that of sondes at 450-500 K $(\sim 16-20 \mathrm{~km})$ in 1994-2000. Additionally, a similar bias was noted when lidar ozone was compared to ECC sondes and SAGE II ozone at $16-19 \mathrm{~km}$ in 1985 2000 too (Godin-Beekmann et al., 2004). Further, Nardi et al. (2008) show comparatively larger negative bias around $100 \mathrm{hPa}$, when OHP lidar ozone was compared to HIRDLS (High Resolution Dynamics Limb Sounder) ozone.

Figure 3 (right panel) shows the relative variations of HALOE against lidar ozone from 1991 to 2005 . The deviations are mostly within $\pm 5 \%$ at all altitudes while they exceed $\pm 10 \%$ at $16-20$ and $38-42 \mathrm{~km}$. HALOE provided fewer collocations when compared to other longer data sets. Not even a single matching event is obtained in the lower 


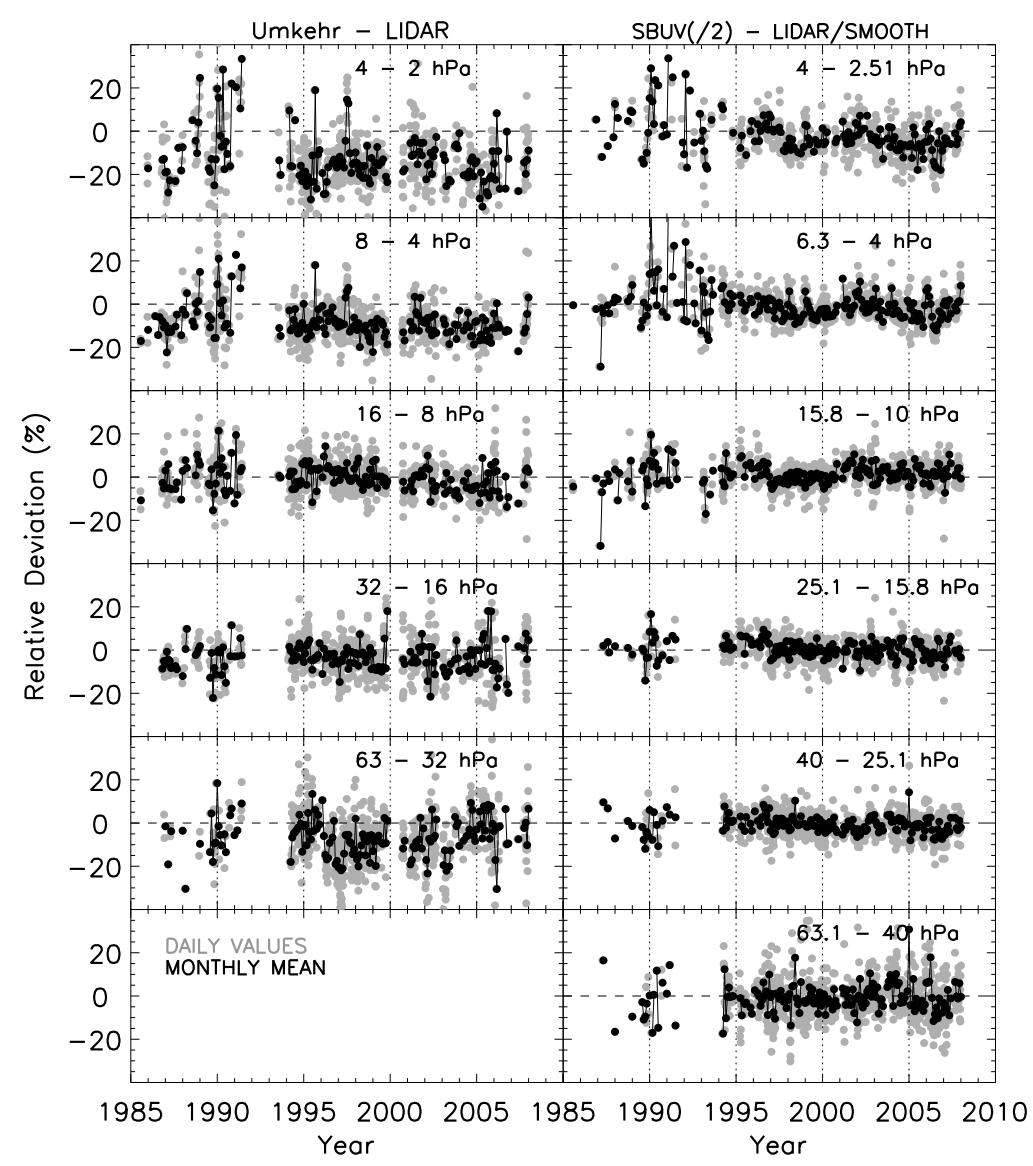

Fig. 4. Same as Fig. 3, but for Umkehr with lidar (left panel) and for SBUV(/2) with lidar convolved using SBUV(/2) ozone averaging kernels (right panel).

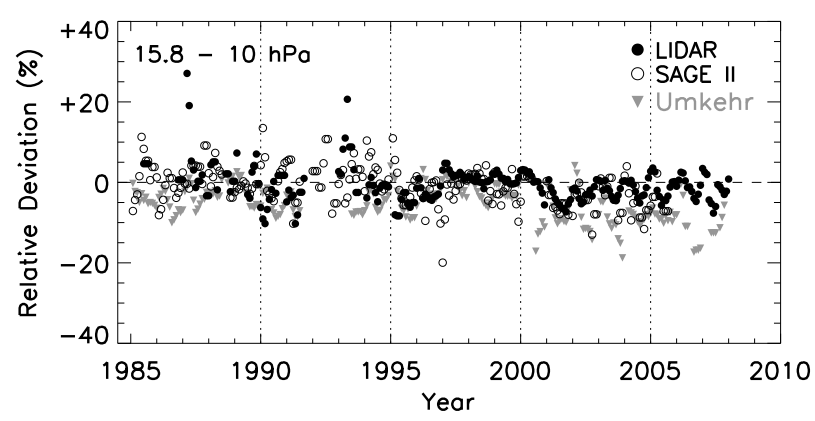

Fig. 5. Monthly average of the relative differences of collocated ozone column measurements of SBUV(/2) with lidar, SAGE II and Umkehr at $15.8-10 \mathrm{hPa}$. The dashed horizontal line represents $0 \%$ and the dotted vertical lines represent year 1990, 1995, 2000, and 2005. Data are smoothed by 3-month running mean.

stratosphere before 1994 after filtering both data following the Mount Pinatubo volcanic eruption.

Figure 4 (left panel) presents the comparison of Umkehr ozone with that of lidar from 1985 to 2007. The comparison is based on Umkehr pressure layers instead of geometric altitudes. The analysis presents its best agreement at $32-16 \mathrm{hPa}$ $(\sim 25 \mathrm{~km})$ and $16-8 \mathrm{hPa}(\sim 30 \mathrm{~km})$ until 2000 , where deviations are within $\pm 5 \%$. A negative bias is seen at other levels. At $63-32 \mathrm{hPa}(\sim 21 \mathrm{~km})$ and $8-4 \mathrm{hPa}(\sim 35 \mathrm{~km})$, the relative differences are around $\pm 10 \%$ and slightly larger at 4 $2 \mathrm{hPa}(\sim 40 \mathrm{~km})$. The higher negative differences at $4-2 \mathrm{hPa}$ is likely be due to the lower ozone values of Umkehr caused by the internal scattered light problems of its Dobson. It can be rectified by applying a stray light correction to the Umkehr data (Petropavlovskikh et al., 2009).

Figure 4 (right panel) displays the time series of comparison between SBUV(/2) and convolved lidar ozone in 19852007. An excellent agreement within $\pm 4 \%$ is found at $40-$ $25.1 \mathrm{hPa}(\sim 23 \mathrm{~km})$ and $25.1-15.8 \mathrm{hPa}(\sim 26 \mathrm{~km})$. At $15.8-$ $10 \mathrm{hPa}(\sim 29 \mathrm{~km})$ and $6.3-4 \mathrm{hPa}(\sim 35 \mathrm{~km})$ the differences lie within \pm 5 and $\pm 10 \%$ respectively, except for a few points prior to 1994 . At these altitudes the deviations decrease from 1995 to 1997 followed by an increase until 2003, and again a decrease afterwards. A similar result is also shown by Terao et al. (2007) when SBUV(/2) data are compared with ozonesondes. A sudden increase, from -0.2 to $6 \%$, is 


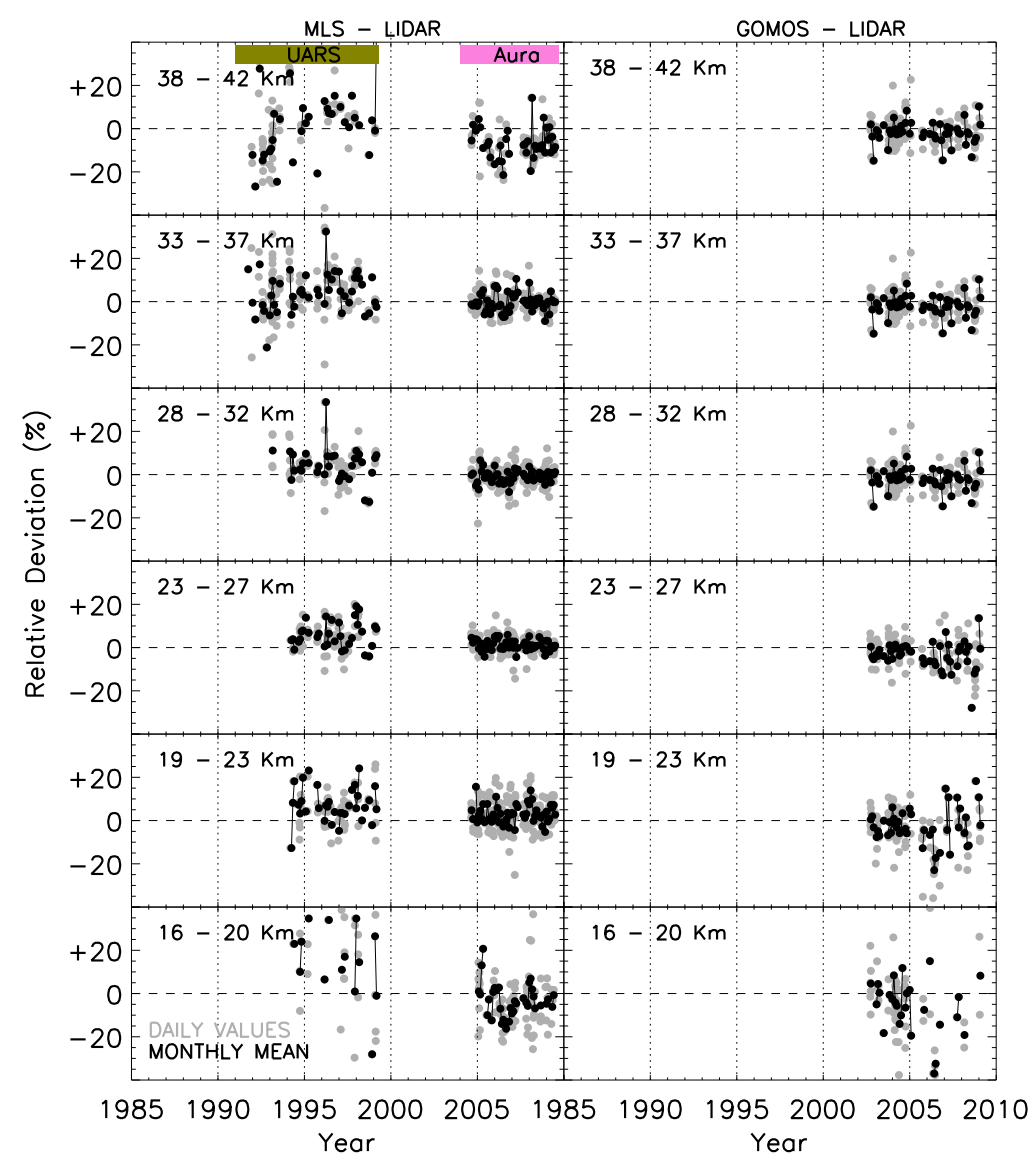

Fig. 6. Same as Fig. 3, but for MLS on UARS and Aura satellites (left panel) and GOMOS (right panel). The period of observations of UARS MLS and Aura MLS are shown with respective colour shades, as for Fig. 1.

observed at 15.8-10 hPa in 2000-2001 and also at 6.3-4 and $4-2.51 \mathrm{hPa}(\sim 39 \mathrm{~km})$ to a lesser extent.

To closely examine the increase in 2001 found at 15.8 $10 \mathrm{hPa}, \mathrm{SBUV}(/ 2)$ ozone column profiles were compared to all OHP Umkehr data and SAGE II measurements extracted above OHP. To perform the comparisons, the Umkehr ozone columns were interpolated to SBUV(/2) pressure levels and SAGE II ozone number density profiles are analysed as discussed previously for SBUV(/2)-lidar (non-convolved) comparison. Relative differences were determined at the SBUV(/2) pressure levels as:

$\Delta \mathrm{O}_{3 \mathrm{SBUV}}(i, j)=\frac{\operatorname{Meas}(i, j)-\operatorname{SBUV}(/ 2)(i, j)}{\operatorname{SBUV}(/ 2)(i, j)} \times 100 \%$

where $i=$ coincident day, $j=$ pressure, and "Meas" represents Umkehr, lidar and SAGE II.

The compared results were smoothed by 3-month running average and are presented in Fig. 5. Relative differences of SBUV(/2) with SAGE II and lidar show similar behaviour, whereas Umkehr gives negative differences consistently. In 2001-2002, all data sets exhibit larger negative deviations compared to other years. In this study, we use SBUV/NOAA-16 data from October 2000 to December 2002. The aforesaid deviations can be due to the comparatively larger ozone values of SBUV/NOAA-16 as discussed in Nazaryan et al. (2005), who compared SBUV/2 with SAGE II, in Fioletov et al. (2006), who analysed SBUV(/2) with Umkehr, SAGE II and ozonesondes, and in Nazaryan et al. (2007), who compared SBUV/2 with HALOE. It should be noted, however, that the Dobson instrument at OHP was struck by lightning in 1999 and 2002, and these events have affected the quality of Umkehr data thereafter.

\subsubsection{Short-term data sets}

Figure 6 shows the comparison of lidar ozone with the shorter data sets MLS (left panel) and GOMOS (right panel). UARS MLS shows its best agreement in 23-27 and 28$32 \mathrm{~km}$ with differences of $\pm 10 \%$ and are somewhat higher at other altitudes. As the valid pressure range of UARS MLS is $100-0.22 \mathrm{hPa}$, we obtained only a few number of matching events at $16-20 \mathrm{~km}$. Aura MLS produced smaller differences $( \pm 5 \%)$ at all altitudes except at $16-20$ and $38-42 \mathrm{~km}$ where differences reach $\pm 10 \%$. GOMOS exhibits small deviations 


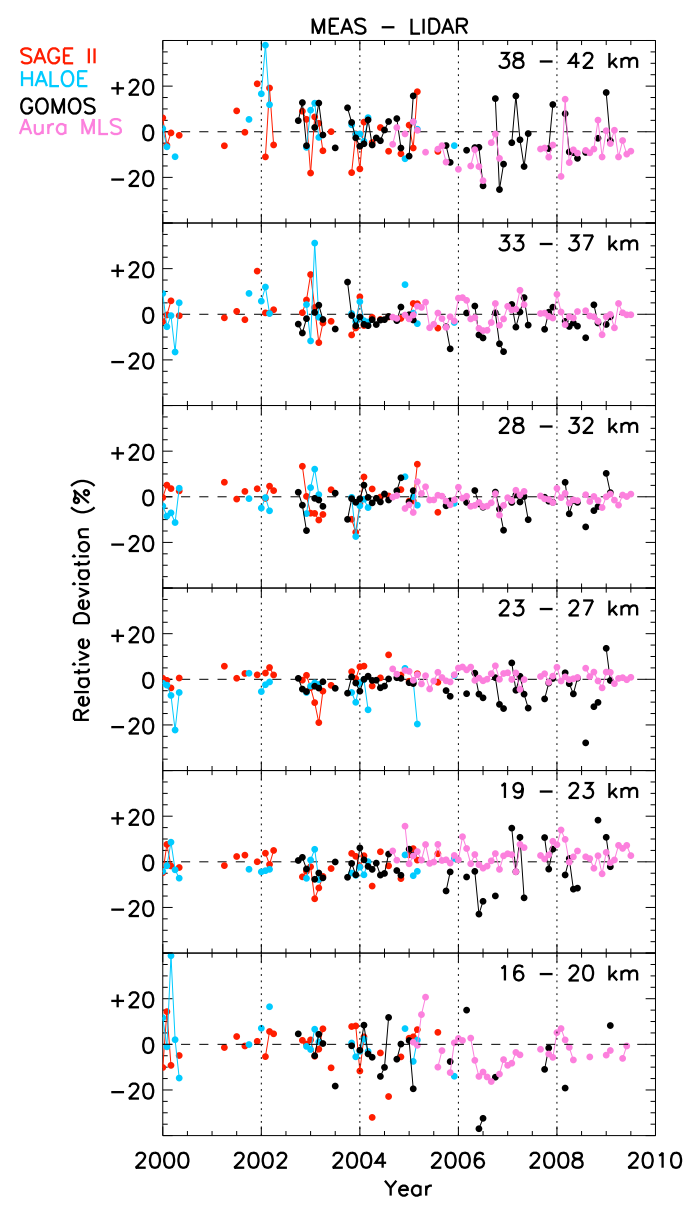

Fig. 7. Time series of the monthly average of the relative differences of SAGE II, HALOE, GOMOS and Aura MLS with lidar. The dashed horizontal line represents $0 \%$ and the dotted vertical lines represent years 2002, 2004, 2006 and 2008.

from 2002 to 2005 at all altitudes. After 2005, the variations are a little higher because of the degradation of GOMOS data due to an increase in its detector noise.

Figure 7 shows the time series of the monthly average of the relative differences of SAGE II, HALOE, GOMOS and Aura MLS with lidar ozone. It presents an overview of how the long-term and short-term satellite data behave during their overlapping period (2002-2005). Aura MLS provides continuous measurements with small differences of about $\pm 5 \%$, whereas GOMOS exhibits large variability in the monthly averages and are discontinuous too. During the overlapping period, the differences are almost the same for all data sets and are within $\pm 5 \%$ at $19-23$ and $23-27 \mathrm{~km}$, and within $\pm 10 \%$ at $28-32$ and $33-37 \mathrm{~km}$. The deviations are slightly larger at $16-20$ and $38-42 \mathrm{~km}$. Therefore, a combined time series of SAGE II and HALOE with GOMOS and Aura MLS provide a good data set for the evaluation of the vertical distribution and temporal evolution of ozone from 1980s to the present. It also constitutes a 30 year data pool for the study of stratospheric ozone trends. The drifts of SAGE II, HALOE, GOMOS and Aura MLS with respect to lidar measurements are discussed in Sect. 4.3.

\subsection{Average biases}

The vertical distribution of average relative deviations in each season and over the period of each data set are shown in Fig. 8, for the long-term (top panel) and short-term (bottom panel) data sets. In general, comparisons of various observations with the lidar measurements exhibit smaller differences, within $\pm 5 \%$, at $20-40 \mathrm{~km}$ and somewhat higher differences outside this range. Below $20 \mathrm{~km}$ the atmospheric variability is larger and the accuracy and precision of ozone measurements are lower. Above $40 \mathrm{~km}$ the signal to noise ratio of lidar measurements is lower and the precision varies from 10 to $30 \%$ in $40-45 \mathrm{~km}$ and exceeds $50 \%$ at $50 \mathrm{~km}$. This larger uncertainty of lidar profiles induces relatively larger deviations above $40 \mathrm{~km}$. This is also reflected in the comparison between mean and median. Both give similar results at $20-40 \mathrm{~km}$ while the median deviates from the mean below 20 and above $40 \mathrm{~km}$.

In order to compare all measurements in a common scale, geometric altitudes are preferred. Therefore, geometric altitudes corresponding to Umkehr and SBUV(/2) mid-pressure levels are computed from the lidar profiles and are averaged over the comparison period (1985-2007). The mid-pressure levels of Umkehr layers 4 to 8 are respectively 48, 24, 16, 6 and $3 \mathrm{hPa}$ and their corresponding geometric altitudes are in turn $21,25,30,35$ and $40 \mathrm{~km}$.

\subsubsection{Long-term data sets}

On average, SAGE II, SBUV(/2) and ozonesondes provide similar results up to $30 \mathrm{~km}$ even though ozonesondes show a bias of about $-6 \%$ around $17-19 \mathrm{~km}$. This negative bias can be due to the facts discussed in Sect. 4.1.1. Up to $30 \mathrm{~km}$, HALOE yields larger negative deviations compared to SAGE II, consistent with the results of Nazaryan et al. (2007) and Froidevaux et al. (2008), who also noted lower HALOE ozone values as compared to SAGE II at these altitudes. Above $30 \mathrm{~km}$, SAGE II and HALOE exhibit positive deviations while SBUV(/2) gives mostly negative deviations. SAGE II shows an excellent agreement of $\pm 1 \%$ with the lidar in the $17-41 \mathrm{~km}$ range. Ozonesondes and $\operatorname{SBUV}(/ 2)$ also provide $\pm 1 \%$ difference at $20-30 \mathrm{~km}$. Umkehr stands out with slightly larger negative deviations. However, the stray light correction to the Umkehr data could reduce these biases, by about $6 \%$, particularly at $8-4$ and 4 $2 \mathrm{hPa}$ (Petropavlovskikh et al., 2009). The best agreement is found at $16-8 \mathrm{hPa}$ with near zero bias.

Root mean square (RMS) difference is evaluated in order to determine which instrument agrees best with the lidar. RMS is estimated vertically for the long-term data sets from 


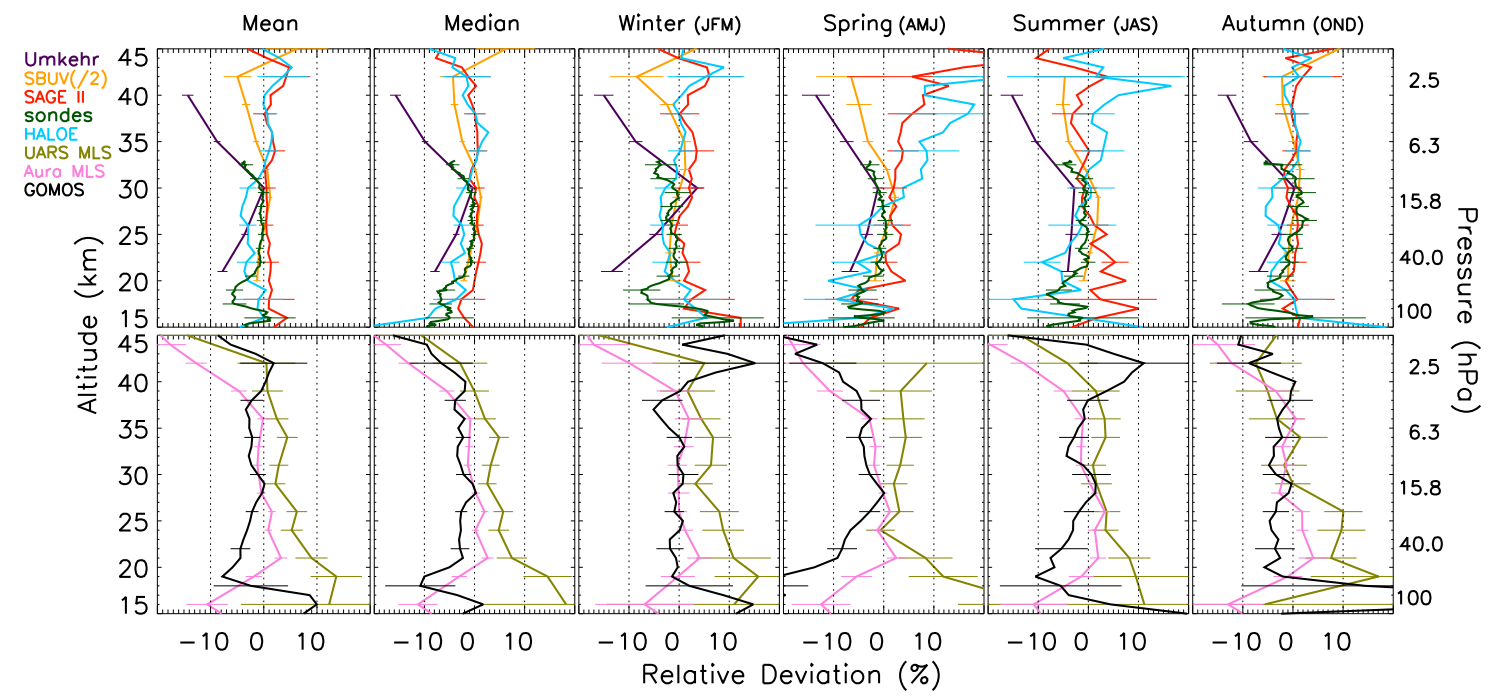

Fig. 8. Vertical distribution of average relative differences of the coincident ozone measurements of various observations with lidar. Top panel: instruments with more than 10 years of data. Bottom panel: instruments with less than 10 years of data. The dotted vertical lines represent $-10,0$, and $10 \%$ and the error bars correspond to twice the standard error. Approximate pressure levels corresponding to the geometric altitudes are also shown on the right axes.

the relative differences, averaged over the respective periods, as:

$\mathrm{RMS}=\sqrt{\frac{\sum_{j=1}^{n}\left(\overline{\Delta \mathrm{O}_{3}(j)}\right)^{2}}{n}}$

where

$\overline{\Delta \mathrm{O}_{3}(j)}=\frac{\sum_{i, j} \Delta \mathrm{O}_{3}(i, j)}{N}$

where $\Delta \mathrm{O}_{3}(i, j)$ is as given in Eq. 2, $i=$ coincident day, $j=$ altitude, $n=$ total number of altitudes, and $N=$ number of profiles.

The altitude levels are $15-45 \mathrm{~km}$ for SAGE II and HALOE; $15-33 \mathrm{~km}$ for ozonesondes; $20-45 \mathrm{~km}$ for $\operatorname{SBUV}(/ 2)$ and $20-40 \mathrm{~km}$ for Umkehr. In terms of RMS, SAGE II and Umkehr provide respectively the lowest $(2.1 \%)$ and the highest $(8.4 \%)$ value. HALOE, SBUV(/2) and ozonesondes give RMS value of $2.7,3$ and $2.5 \%$, respectively.

Seasonally, the differences are smaller in absolute scales in autumn and winter for all measurements except for Umkehr at $63-32$ and $4-2 \mathrm{hPa}$, and for SBUV(/2) around $40 \mathrm{~km}$ in winter. Larger biases are observed for SAGE II and HALOE in spring and summer. This is due to their limited sampling in the northern mid-latitudes during these seasons. For example, only one profile among the 4 coincidences of HALOE with lidar in spring reached up to $45 \mathrm{~km}$. Hence, the relative differences over the period are mainly weighted by the winter and autumn sampling for HALOE and SAGE II. Ozonesondes do not show any seasonal dependence, whereas Umkehr shows a positive deviation at $16-8 \mathrm{hPa}$ in winter.

For ozonesondes, we investigated the impact of multiplying sonde profiles with the correction factor (as noted in Sect. 2.1.2). The vertical profile of average deviations computed with and without multiplying by the correction factor are shown in Fig. 9 for the period 1991-2009. The multiplication by correction factor yields smaller differences in the $15-33 \mathrm{~km}$ range and the ozonesondes - lidar differences are very close to zero around $16 \mathrm{~km}$ and at $21-31 \mathrm{~km}$. These results show that the quality of the sonde profiles, as evaluated by the lidar measurements, is improved when the correction factor is applied.

\subsubsection{Short-term data sets}

Figure 8 (lower panel) shows the average relative differences calculated for the short-term data sets in their respective periods. Aura MLS shows small variations, within $\pm 2 \%$ at $19-38 \mathrm{~km}$, and it systematically underestimates lidar ozone below 20 and above $38 \mathrm{~km}$. Compared to Aura MLS, UARS MLS exhibits slightly higher bias, with positive average differences at $16-40 \mathrm{~km}$ throughout the period except in autumn above $28 \mathrm{~km}$. Livesey et al. (2003) compared UARS MLS ozone with SAGE II, ozonesondes and lidar data, and found positive deviations in most cases, matching our results. A small positive bias is estimated for Aura MLS in the lower stratosphere when compared with SAGE II, HALOE (Froidevaux et al., 2008) and ozonesondes (Jiang et al., 2007). In contrast, in agreement with our results, the 


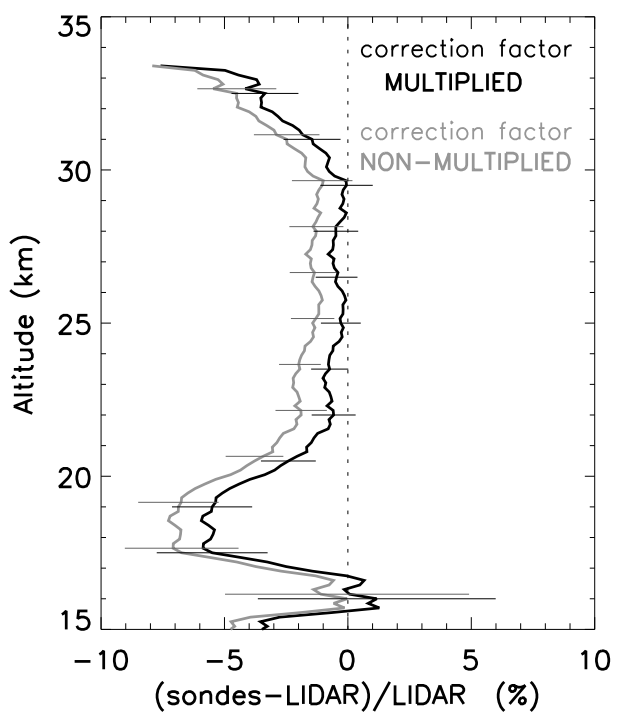

Fig. 9. Average relative deviation of ozone from lidar and ozonesondes, with and without multiplying by correction factor. The dotted vertical line represents $0 \%$ and the error bars represent twice the standard error.

comparison of Aura MLS with the ground-based microwave radiometer (Boyd et al., 2007) and lidar (Jiang et al., 2007) data do not exhibit a positive bias in the lower stratosphere.

GOMOS observations show smaller biases with lidar measurements at $28-40 \mathrm{~km}$ when averaged over the period. Below $28 \mathrm{~km}$, negative differences are found down to $18 \mathrm{~km}$ and positive ones in the range $15-17 \mathrm{~km}$. Above $40 \mathrm{~km}$, lidar overestimates ozone as compared to GOMOS. Seasonal differences in winter and autumn are very similar to the whole period averages except above $40 \mathrm{~km}$ in winter. In spring, the negative bias of GOMOS data is more pronounced in the lower and upper stratosphere. In summer, discrepancies are larger but the comparison is performed on very few collocated measurements, 28 in total over the period. In order to check our results with those of other studies, we compared lidar and GOMOS ozone using a spatial criterion of $800 \mathrm{~km}$ and a temporal criterion of $\pm 20 \mathrm{~h}$, similar to the criteria set in Van Gijsel et al. (2009), which yielded very similar results (not shown).

\subsection{Drift in temporal evolution of ozone differences}

In order to evaluate possible drifts between various data sets and the lidar observations, linear regressions were computed at all altitudes, from the monthly averaged time series of ozone relative differences. Although some time series show non-linear variation as a function of time (e.g. in the case of SBUV(/2) at $15.8-10 \mathrm{hPa}$ or ozone soundings), linear regression provides a simple way to check the drifts in various observational records. The significance of the slope is evaluated by using the standard deviation $(\sigma)$ times two (or a $95 \%$ confidence level), with $\sigma$ given by (Press et al., 1989):

$$
\sigma(j)=\frac{\sqrt{\frac{\chi^{2}(j)}{N(j)-2}}}{\sqrt{\sum_{i=1}^{N(j)}\left(x_{i}-\bar{x}\right)^{2}}}
$$

where $\chi^{2}(j)=\sum_{i=1}^{N(j)}\left(y_{i}-a-b x_{i}\right)^{2}, N=$ number of months, $x=$ month,$y=$ monthly relative difference, $a=\mathrm{y}$-intercept, $b=$ slope, and $j=$ altitude or pressure level.

Due to the reduced sampling of lidar measurements in the earlier period, the number of coincidences is smaller prior to 1994 . After 1994 the number of lidar profiles increased due to the upgrade of the experimental set up and improved observational capacity at OHP. Therefore, linear regressions are evaluated over the respective period of each data set in 1985-2009 and 1994-2009. The starting (e.g. 1985 or 1994) and ending (2009) year of the analyses depend on the availability of the observations. Results for both calculations for the long-term data are displayed separately in Fig. 10 (left and middle panels). As shown in the figure, no striking difference is found by separating both periods, except for SAGE II and Umkehr above $35 \mathrm{~km}$, with smaller drifts in 1994-2009. Also SAGE II exhibits larger drifts at 18-20 km in 1994-2005 as compared to that in 1985-2005. As for the average biases, the slopes are generally larger below 20 and above $40 \mathrm{~km}$. In the range $20-40 \mathrm{~km}$, they are less than $\pm 0.5 \% \mathrm{yr}^{-1}$.

The slope and standard deviation are also evaluated at specific altitudes as given in Figs. 3 and 4, and are summarised in Table 3. We discuss the derived drifts at these reference altitudes for simplicity reasons.

In the case of $\operatorname{SBUV}(/ 2)$, a significant drift of $\sim$ $\pm 0.2 \% \mathrm{yr}^{-1}$ with respect to lidar is estimated at $25.1-15.8$ and 6.3-4 hPa in 1985-2007 and at 40-25.1, 25.1-15.8 and $15.8-10 \mathrm{hPa}$ in $1994-2007$. At $6.3-4 \mathrm{hPa}$, larger deviations are found in the early 1990s, which could explain the significant slope calculated over the period. The shifts found at this pressure level and at $15.8-10 \mathrm{hPa}$ in 2001 (Fig. 4) point out the inadequacy of using a simple linear regression over successive SBUV(/2) records at some pressure levels. SAGE II exhibits a significant slope of $-0.59 \% \mathrm{yr}^{-1}$ at $19-23 \mathrm{~km}$ in 1994-2005 due to positive differences in 1994-1996 followed by negative ones in 2004-2005. Umkehr observations also show significant drift of $-0.3 \% \mathrm{yr}^{-1}$ with respect to lidar at 16-8 and 8-4 hPa in 1985-2007 and 1994-2007. At 4-2 $\mathrm{hPa}$, a relative drift of $-0.53 \% \mathrm{yr}^{-1}$ is detected in $1985-$ 2007. At these levels the relative differences have higher positive values at the beginning of the periods and higher negative values at the end of the period, which result in significant slopes over these periods. HALOE shows somewhat larger slopes than other measurement records at $20-25 \mathrm{~km}$, but due to larger error bars the relative drifts are not significant. 


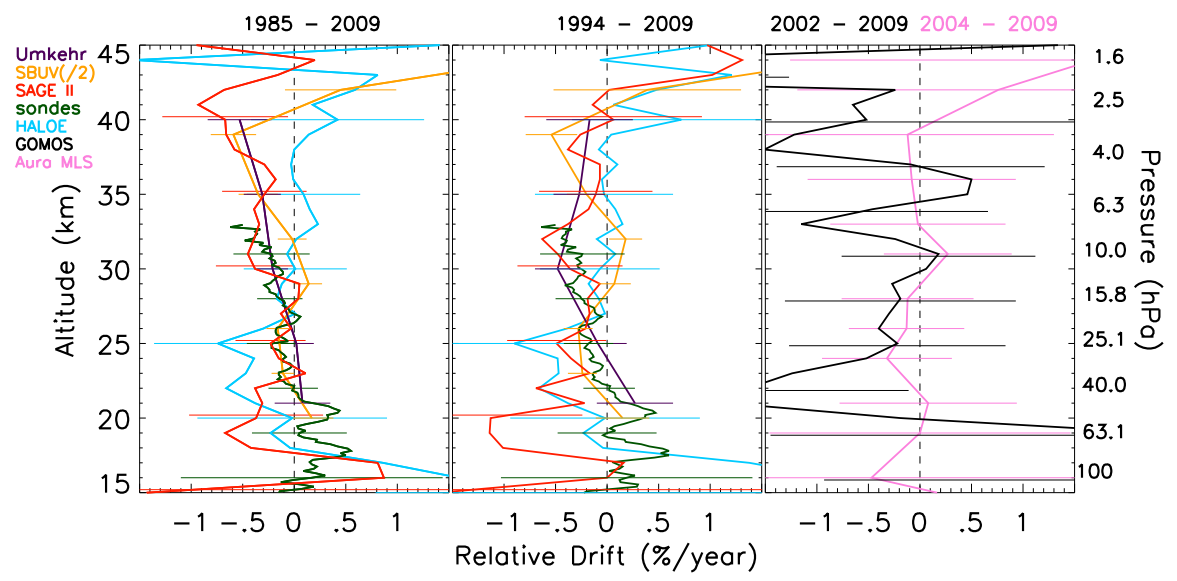

Fig. 10. Vertical distribution of the slopes calculated from monthly average of the relative differences of long-term (left and middle panels) and short-term (right panel) data sets with lidar data. The slopes are estimated in two periods, in 1985-2009 and 1994-2009, for the longterm data. The beginning (e.g. 1985, 1994, 2002, 2004) and ending (2009) year of the analyses depend on the availability of the respective observations during the period. Please see the text for more details. The dashed vertical line represents $0 \% \mathrm{yr}^{-1}$ and the error bars represent twice the standard deviation of the slope. Approximate pressure levels corresponding to the geometric altitudes are also shown on the right axis.

A significant slope of $-0.33 \% \mathrm{yr}^{-1}$ is estimated for ozonesonde - lidar comparison at $30 \mathrm{~km}$ in both periods, which can be due to the reduced accuracy of ozonesonde data at this altitude. The slopes are less than $\pm 0.6 \% \mathrm{yr}^{-1}$ at $15-33 \mathrm{~km}$ in these periods. Further, relative drifts were also estimated for two other periods (1994-2001 and 20022009 ) to test the negative deviations found at $16-20 \mathrm{~km}$ in 1994-2006. Negative and positive slopes were computed from 16 to $29 \mathrm{~km}$ in $1994-2001$ and 2002-2009 respectively, but were less than $\pm 1.5 \% \mathrm{yr}^{-1}$ at $21-33 \mathrm{~km}$ in both periods. At $16-20 \mathrm{~km}$, the slopes were more negative in 1994-2001 and more positive in 2002-2009, with maximum of -3.1 and $2.8 \% \mathrm{yr}^{-1}$, respectively.

The drifts of the short-term data sets GOMOS and Aura MLS are also estimated with respect to lidar measurements in 2002-2009 and 2004-2009, respectively, and are shown in Fig. 10 (right panel). GOMOS shows small drifts less than $\pm 1 \% \mathrm{yr}^{-1}$ between 24 and $37 \mathrm{~km}$ and of about \pm 1.6 to $\pm 6 \% \mathrm{yr}^{-1}$ outside this range. Aura MLS exhibits smaller drifts than those of GOMOS, ranging from \pm 0.01 to $\pm 0.7 \% \mathrm{yr}^{-1}$ at $15-42 \mathrm{~km}$. As mentioned in Sect. 4.1.2, the degradation of the GOMOS data after 2005 could play a role in contributing large drifts. GOMOS provides relatively fewer number of coincidences with the lidar and that results in high variability in the monthly averages, and hence, larger drifts on a short period. The estimated drifts are not significant for Aura MLS at any altitude, whereas significant drifts are estimated for GOMOS at 21, 22 and $43 \mathrm{~km}$ of the order of $-1.86,-1.67$ and $-6 \% \mathrm{yr}^{-1}$, respectively.

Our drift estimates are in generally good agreement with those found in other studies. In this work, SBUV(/2)-lidar, Umkehr-lidar, sondes-lidar, SAGE II-lidar, HALOE-lidar,
GOMOS-lidar and Aura MLS-lidar comparisons provide slopes generally less than $\pm 0.5 \% \mathrm{yr}^{-1}$ in the $20-40 \mathrm{~km}$ range and are larger beyond this range. The study by Nazaryan et al. (2005) mentions slopes of less than 0.5 and $3 \% \mathrm{yr}^{-1}$ for the time series of SAGE II with SBUV/2 data sets NOAA11 and NOAA-16 ozone respectively, in the $20-50 \mathrm{~km}$ range. Similarly, the slopes of HALOE with NOAA-11 and NOAA16 are less than 1 and $2 \% \mathrm{yr}^{-1}$ respectively (Nazaryan et al., 2007), consistent with our results. Cunnold et al. (2000) also studied instrumental drifts for different measurement techniques. They show SBUV-SAGE II slopes of less than $\pm 0.5 \% \mathrm{yr}^{-1}$ at $20-40 \mathrm{~km}$ and around $1.5 \% \mathrm{yr}^{-1}$ at $45 \mathrm{~km}$ in the 1984-1989 period at northern mid-latitudes. In 19891994, SBUV/2-SAGE II slopes are around $1 \% \mathrm{yr}^{-1}$ at 25 $45 \mathrm{~km}$ and are very small at $20 \mathrm{~km}$. UARS MLS-SAGE and UARS MLS-HALOE provide slopes of around $\pm 1 \% \mathrm{yr}^{-1}$ at $25-45 \mathrm{~km}$ in 1991-1996. Similarly, our results are similar to those found in SPARC (1998), for lidar-SAGE II comparison at OHP. Thus, our analyses of the long-term evolution and drifts of ozone for various techniques are in good agreement with the ozone trend studies for the northern mid-latitudes even if no other works perform the evaluation of drifts for more than 15 years using a variety of measurements, as performed in this study. Also, the short-term data with relative drifts comparable to those of the long-term data, would be an asset for their use in the future ozone trend studies.

\section{Conclusions}

This study presents the first elaborate quantitative bias and drift estimations using the OHP lidar ozone measurements 
Table 3. The slope $(S)$ and twice its standard deviation $(\sigma)$ deduced from the monthly averages of the relative differences $(\%)$ at selected altitude levels for the periods 1985-2009 $\left(S_{8509}\right)$ and 1994-2009 $\left(S_{9409}\right)$. The two periods are chosen because of the upgradation of OHP lidar in 1993. Umkehr and SBUV(/2) are given on pressure levels.

\begin{tabular}{|c|c|c|c|c|c|c|c|c|c|c|c|c|}
\hline \multirow[t]{2}{*}{ Instrument } & $\begin{array}{r}S_{8509} \pm 2 \sigma \\
\left(\% \mathrm{yr}^{-1}\right)\end{array}$ & $\begin{array}{r}S_{9409} \pm 2 \sigma \\
\left(\% \mathrm{yr}^{-1}\right)\end{array}$ & $\begin{array}{r}S_{8509} \pm 2 \sigma \\
\left(\% \mathrm{yr}^{-1}\right)\end{array}$ & $\begin{array}{r}S_{9409} \pm 2 \sigma \\
\left(\% \mathrm{yr}^{-1}\right)\end{array}$ & $\begin{array}{r}S_{8509} \pm 2 \sigma \\
\left(\% \mathrm{yr}^{-1}\right)\end{array}$ & $\begin{array}{r}S_{9409} \pm 2 \sigma \\
\left(\% \mathrm{yr}^{-1}\right)\end{array}$ & $\begin{array}{r}S_{8509} \pm 2 \sigma \\
\left(\% \mathrm{yr}^{-1}\right)\end{array}$ & $\begin{array}{r}S_{9409} \pm 2 \sigma \\
\left(\% \mathrm{yr}^{-1}\right)\end{array}$ & $\begin{array}{r}S_{8509} \pm 2 \sigma \\
\left(\% \mathrm{yr}^{-1}\right)\end{array}$ & $\begin{array}{r}S_{9409} \pm 2 \sigma \\
\left(\% \mathrm{yr}^{-1}\right)\end{array}$ & $\begin{array}{r}S_{8509} \pm 2 \sigma \\
\left(\% \mathrm{yr}^{-1}\right)\end{array}$ & $\begin{array}{r}S_{9409} \pm 2 \sigma \\
\left(\% \mathrm{yr}^{-1}\right)\end{array}$ \\
\hline & \multicolumn{2}{|c|}{$16-20 \mathrm{~km}$} & \multicolumn{2}{|c|}{$19-23 \mathrm{~km}$} & \multicolumn{2}{|c|}{$23-27 \mathrm{~km}$} & \multicolumn{2}{|c|}{$28-32 \mathrm{~km}$} & \multicolumn{2}{|c|}{$33-37 \mathrm{~km}$} & \multicolumn{2}{|c|}{$38-42 \mathrm{~km}$} \\
\hline SAGE II & $-0.42 \pm 0.77$ & $-0.74 \pm 0.80$ & $-0.31 \pm 0.32$ & $-0.59 \pm 0.43$ & $-0.10 \pm 0.23$ & $-0.29 \pm 0.33$ & $-0.18 \pm 0.32$ & $-0.32 \pm 0.42$ & $-0.33 \pm 0.36$ & $-0.22 \pm 0.49$ & $-0.51 \pm 0.54$ & $-0.01 \pm 0.69$ \\
\hline HALOE & $0.26 \pm 0.97$ & $0.26 \pm$ & $-0.25 \pm 0.49$ & $-0.25 \pm 0.49$ & $-0.47 \pm 0.49$ & $-0.47 \pm 0.49$ & $-0.10 \pm 0.45$ & $-0.08 \pm 0.50$ & $0.08 \pm 0.49$ & $0.05 \pm 0.59$ & $0.31 \pm 0.66$ & $0.46 \pm 0.75$ \\
\hline \multirow[t]{2}{*}{ ozonesondes } & $0.25 \pm 0.34$ & $0.25 \pm 0.34$ & $0.15 \pm 0.24$ & $0.13 \pm 0.24$ & $-0.21 \pm 0.21$ & $-0.20 \pm 0.21$ & $-0.33 \pm 0.28$ & $-0.33 \pm 0.30$ & & & & \\
\hline & \multicolumn{2}{|c|}{$63.1-40 \mathrm{hPa}$} & \multicolumn{2}{|c|}{$40-25.1 \mathrm{hPa}$} & \multicolumn{2}{|c|}{$25.1-15.8 \mathrm{hPa}$} & \multicolumn{2}{|c|}{$15.8-10 \mathrm{hPa}$} & \multicolumn{2}{|c|}{$6.31-4 \mathrm{hPa}$} & \multicolumn{2}{|c|}{$4-2.51 \mathrm{hPa}$} \\
\hline \multirow[t]{3}{*}{$\operatorname{SBUV}(/ 2)$} & $0.17 \pm 0.21$ & $0.15 \pm 0.26$ & $-0.11 \pm 0.12$ & $-0.24 \pm 0.14$ & $-0.16 \pm 0.11$ & $-0.28 \pm 0.15$ & $-0.02 \pm 0.14$ & $0.18 \pm 0.16$ & $-0.35 \pm 0.19$ & $-0.19 \pm 0.19$ & $0.45 \pm 0.54$ & $0.39 \pm 0.91$ \\
\hline & & & \multicolumn{2}{|c|}{$63-32 \mathrm{hPa}$} & \multicolumn{2}{|c|}{$32-16 \mathrm{hPa}$} & \multicolumn{2}{|c|}{$16-8 \mathrm{hPa}$} & \multicolumn{2}{|c|}{$8-4 \mathrm{hPa}$} & \multicolumn{2}{|c|}{$4-2 \mathrm{hPa}$} \\
\hline & & & $0.08 \pm 0.27$ & $0.27 \pm 0.37$ & $0.02 \pm 0.17$ & $-0.09 \pm 0.28$ & $-0.21 \pm 0.15$ & $-0.48 \pm 0.22$ & $-0.31 \pm 0.18$ & $-0.27 \pm 0.25$ & $-0.53 \pm 0.32$ & $-0.17 \pm 0.42$ \\
\hline
\end{tabular}

spanning more than 25 years. It estimates the bias of a number of long and short-term and, ground and space-based observations with respect to the OHP lidar measurements. Although there are some bias estimations from other studies, this is the first study that presents the drifts of various ground-based and satellite measurements, for Aura MLS and GOMOS data in particular. Furthermore, the connection between the pre-2002 (SAGE II and HALOE) and the newer (GOMOS and Aura MLS) data sets is analysed in terms of relative offsets and drifts. With additional data from such instruments in the next few years, the capability should exist to continue to pursue accurate and validated long-term stratospheric ozone trends relevant for ozone recovery paths. Clearly, this work fulfills at least one of the main goals of NDACC, i.e., the evaluation of stability of various groundbased and satellite observations.

We analysed the homogeneity of various observational records of the stratospheric ozone vertical distribution at OHP by comparing lidar measurements with ECC ozonesondes and Umkehr measurements at OHP and with SBUV(/2), SAGE II, HALOE, UARS MLS, Aura MLS and GOMOS satellite observations, extracted above the station. The comparisons show generally the best agreement in the $20-40 \mathrm{~km}$ altitude range with the average deviations within $\pm 5 \%$. The differences are larger below $20 \mathrm{~km}$ due to large atmospheric variability and also because of the lower accuracy and precision of the satellite measurements and above $40 \mathrm{~km}$, because of the lower precision of lidar ozone measurements. Umkehr data show larger negative deviations as compared to other measurements, especially at 63-32 and 4-2 hPa. SBUV(/2) observations display a shift around 2001 at $15.8-10 \mathrm{hPa}$ and to a lesser extent at $6.3-4$ and $4-2.51 \mathrm{hPa}$. SAGE II and HALOE provide relatively less sampling at OHP in spring and summer. The best agreement with the lidar data is found for SAGE II with an RMS difference of $2.1 \%$ in the $15-45 \mathrm{~km}$ range, as compared to the other long-term data sets. The temporal evolution of ozonesondes-lidar comparison shows differences originated from the changes in the ozone receiving system, ozone column data used for normalising the sonde profiles and from the ozone deriving methods.
Hence, a homogenised data are needed for the better evaluation of ozone trends. Shorter observational records such as UARS MLS, Aura MLS and GOMOS were also analysed to check their measurement consistency. UARS MLS displays positive biases and are relatively larger compared to Aura MLS. Aura MLS shows good agreement with the lidar at $20-40 \mathrm{~km}$, but negative deviations above $40 \mathrm{~km}$, with GOMOS also showing such a tendency during some seasons. GOMOS compares well with the lidar at $28-40 \mathrm{~km}$.

Linear regressions were computed on the monthly average difference data sets in order to detect possible drifts with respect to the lidar measurements. Collectively, drifts are generally within $\pm 0.5 \% \mathrm{yr}^{-1}$ at $20-40 \mathrm{~km}$ in both analysed periods (1985-2009 and 1994-2009), and are generally not significant at the $2 \sigma$ level. Aura MLS yields very small and non-significant drifts $\left( \pm 0.01-0.7 \% \mathrm{yr}^{-1}\right)$ at $15-42 \mathrm{~km}$ with the lidar, comparable to those of the long-term data sets. Hence, the tested observational records should generally allow for analyses of the long-term evolution of stratospheric ozone in the northern mid-latitudes.

Acknowledgements. We would like to thank Cathy Boonne for maintaining ETHER data cluster, the NASA Langley Research Center (NASA-LaRC) and the NASA Langley Radiation and Aerosols Branch for providing SAGE II data and, the collaborative institutes of the NASA Langley Research Center for maintaining HALOE data. Work at the Jet Propulsion Laboratory, California Institute of Technology was done under contract with the National Aeronautics and Space Administration. The data used in this publication were obtained as part of the NDACC and are publicly available (see http://www.ndacc.org). The data used in this effort were acquired as part of the activities of NASA's Science Mission Directorate, and are archived and distributed by the Goddard Earth Sciences (GES) Data and Information Services Center (DISC). This work is supported by a funding from the GEOMON (Global Earth Observation and Monitoring of the Atmosphere) European project.

Edited by: G. Vaughan 


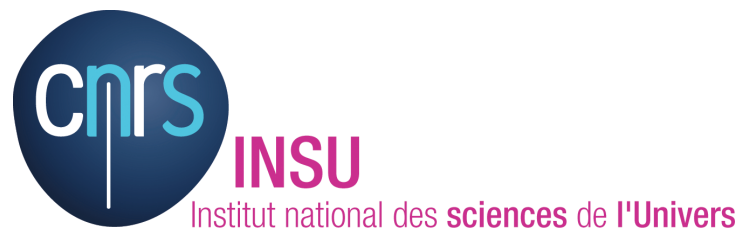

The publication of this article is financed by CNRS-INSU.

\section{References}

Ancellet, G. and Beekmann, M.: Evidence for changes in the ozone concentrations in the free troposphere over southern France from 1976 to 1995, Atmos. Environ., 31, 2835-2851, 1997.

Bhartia, P. K., McPeters, R. D., Mateer, C. L., Flynn, L. E., and Wellemeyer, C.: Algorithm for the estimation of vertical ozone profiles from the backscattered ultraviolet technique, J. Geophys. Res., 101(D13), 18793-18806, 1996.

Bhartia, P. K., Wellemeyer, C. G., Taylor, S. L., Nath, N., and Gopalan, A.: Solar backscatter ultraviolet (SBUV) version 8 profile algorithm, in: Proceedings of the XX Quadrennial Ozone Symposium, edited by: Zerefos, C. S., Int. Ozone Comm., Athens, Greece, 295-296, 2004.

Boyd, I. S., Parrish, A. D., Froidevaux, L., von Clarmann, T., Kyrölä, E., Russell III, J. M., and Zawodny, J. M.: Groundbased microwave ozone radiometer measurements compared with Aura-MLS v2.2 and other instruments at two Network for Detection of Atmospheric Composition Change sites, J. Geophys. Res., 112, D24S33, doi:10.1029/2007JD008720, 2007.

Brühl, C., Roland Drayson, S., Russell III, J. M., Crutzen, P. J., McInerney, J. M., Purcell, P. N., Claude, H., Gernandt, H., McGee, T. J., McDermid, I. S., and Gunson, M. R.: Halogen Occultation Experiment ozone channel validation, J. Geophys. Res., 101(D6), 10217-10240, 1996.

Cunnold, D., Newchurch, M., Flynn, L., Wang, H., Russell, J. M., McPeters, R., Zawodny, J., and Froidevaux, L.: Uncertainties in upper stratospheric ozone trends from 1979 to 1996, J. Geophys. Res., 105(D4), 4427-4444, 2000.

DeLand, M. T., Huang, L.-K., Taylor, S. L., McKay, C. A., Cebula, R. P., Bhartia, P. K., and McPeters, R. D.: Long-term SBUV and SBUV/2 instrument calibration for Version 8 ozone data, in: Proceedings of the XX Quadrennial Ozone Symposium, edited by: Zerefos, C., Univ. of Athens, Greece, 321-322, 2004.

Deshler, T., Mercer, J. L., Smit, H. G. J., Stubi, R., Levrat, G., Johnson, B. J., Oltmans, S. J., Kivi, R., Thompson, A. M., Witte, J., Davies, J., Schmidlin, F. J., Brothers, G., and Sasaki, T.: Atmospheric comparison of electrochemical cell ozonesondes from different manufacturers, and with different cathode solution strengths: The Balloon Experiment on Standards for Ozonesondes, J. Geophys. Res., 113, D04307, doi:10.1029/2007JD008975, 2008.

Dhomse, S., Weber, M., Wohltmann, I., Rex, M., and Burrows, J. P.: On the possible causes of recent increases in northern hemispheric total ozone from a statistical analysis of satellite data from 1979 to 2003, Atmos. Chem. Phys., 6, 1165-1180, doi:10.5194/acp-6-1165-2006, 2006.

Farman, J. C., Gardiner, B. G., and Shanklin, J. D.: Large losses of total ozone in the Antarctica reveal seasonal $\mathrm{ClO}_{\mathrm{x}} / \mathrm{NO}_{\mathrm{x}}$ interaction, Nature, 315, 207-210, 1985.
Fioletov, V. E., Tarasick, D. W., and Petropavlovskikh, I.: Estimating ozone variability and instrument uncertainties from SBUV(/2), ozonesonde, Umkehr, and SAGE II measurements: Short-term variations, J. Geophys. Res., 111, D02305, doi:10.1029/2005JD006340, 2006.

Flynn, L. E., McNamara, D., Beck, C. T., Petropavlovskikh, I., Beach, E., Pachepsky, Y., Li, Y. P., Deland, M., Huang, L. -K., Long, C. S., Tiruchirapalli, R., and Taylor, S.: Measurements and products from the Solar Backscatter Ultraviolet (SBUV/2) and Ozone Mapping and Profiler Suite (OMPS) instruments, Int. J. Remote Sens., 30, 4259-4272, doi:10.1080/01431160902825040, 2009.

Froidevaux, L., Jiang, Y. B., Lambert, A., Livesey, N. J., Read, W. G., Waters, J. W., Browell, E. V., Hair, J. W., Avery, M. A., McGee, T. J., Twigg, L. W., Sumnicht, G. K., Jucks, K. W., Margitan, J. J., Sen, B., Stachnik,,R. A., Toon, G. C., Bernath, P. F., Boone, C. D., Walker, K. A., Filipiak, M. J., Harwood, R. S., Fuller, R. A., Manney, G. L., Schwartz, M. J., Daffer, W. H., Drouin, B. J., Cofield, R. E., Cuddy, D. T., Jarnot, R. F., Knosp, B. W., Perun, V. S., Snyder, W. V., Stek, P. C., Thurstans, R. P., and Wagner, P. A.: Validation of Aura Microwave Limb Sounder stratospheric ozone measurements, J. Geophys. Res. 113, D15S20, doi:10.1029/2007JD008771, 2008.

Godin, S. Carswell, A. I., Donovan, D. P., Claude, H., Steinbrecht, W., McDermid, I. S., McGee, T. J., Gross, M. R., Nakane, H., Swart, D. P., Bergwerff, H. B., Uchino, O., von der Gathen, P., Neuber, R.: Ozone Differential Absorption Lidar Algorithm Intercomparison, Appl. Optics, 38, 6225-6236, 1999.

Godin-Beekmann, S., Porteneuve, J., and Garnier, A.: Systematic DIAL lidar monitoring of the stratospheric ozone vertical distribution at Observatoire de Haute-Provence $\left(43.92^{\circ} \mathrm{N}, 5.71^{\circ} \mathrm{E}\right)$, J. Environ. Monit., 5, 57-67, 2003.

Godin-Beekmann, S., Song, T., Keckhut, P., and Porteneuve, J.: Long-Term Variability of Stratospheric Ozone Monitored by DIAL Measurements at $\mathrm{OHP}\left(44^{\circ} \mathrm{N}, 6^{\circ} \mathrm{E}\right)$, in: Proceedings of the International Laser Radar Conference, edited by: Pappalardo, G. and Amodeo, A., ESA SP-561, 559-562, 2004.

Griesfeller A., Godin-Beekmann S., Petropavlovskikh, I., Nair, P. J., Griesfeller J., Evans, R. D., and Pazmiño, A.: Comparison of long-term stratospheric ozone time series from lidar and Umkehr measurements at Observatoire de Haute-Provence (OHP), $44^{\circ} \mathrm{N}$, $6^{\circ} \mathrm{E}$, in preparation, 2011.

Guirlet, M., Keckhut, P., Godin, S., and Mégie, G.: Description of the long-term ozone data series obtained from different instrumental techniques at a single location: the Observatoire de Haute-Provence $\left(43.9^{\circ} \mathrm{N}, 5.7^{\circ} \mathrm{E}\right)$, Ann. Geophys., 18, 13251339, doi:10.1007/s00585-000-1325-y, 2000.

Hauchecorne, A., Bertaux, J. L., Dalaudier, F., Keckhut, P., Lemennais, P., Bekki, S., Marchand, M., Lebrun, J. C., Kyrölä, E., Tamminen, J., Sofieva, V., Fussen, D., Vanhellemont, F., Fanton d'Andon, O., Barrot, G., Blanot, L., Fehr, T., and Saavedra de Miguel, L.: Response of tropical stratospheric $\mathrm{O}_{3}, \mathrm{NO}_{2}$ and $\mathrm{NO}_{3}$ to the equatorial Quasi-Biennial Oscillation and to temperature as seen from GOMOS/ENVISAT, Atmos. Chem. Phys., 10, 8873-8879, doi:10.5194/acp-10-8873-2010, 2010.

Jiang, Y. B., Froidevaux, L., Lambert, A., Livesey, N. J., Read, W. G., Waters, J. W., Bojkov,B., Leblanc, T., McDermid, I. S., Godin-Beekmann, S., Filipiak, M. J., Harwood, R. S., Fuller, R. A., Daffer, W. H., Drouin, B. J., Cofield, R. E., Cuddy, D. T., 
Jarnot, R. F., Knosp, B. W., Perun, V. S., Schwartz, M. J., Snyder, W. V., Stek, P. C., Thurstans, R. P., Wagner, P. A., Allaart, M., Andersen, S. B., Bodeker, G., Calpini, B., Claude, H., Coetzee, G., Davies, J., De Backer, H., Dier, H., Fujiwara, M., Johnson, B., Kelder, H., Leme, N. P., König-Langlo, G., Kyro, E., Laneve, G., Fook, L. S., Merrill, J., Morris, G., Newchurch, M., Oltmans, S., Parrondos, M. C., Posny, F., Schmidlin, F., Skrivankova, P., Stubi, R., Tarasick, D., Thompson, A., Thouret, V., Viatte, P., Vömel, H., von Der Gathen, P., Yela, M., and Zablocki, G.: Validation of Aura Microwave Limb Sounder Ozone by ozonesonde and lidar measurements, J. Geophys. Res., 112, D24S34, doi:10.1029/2007JD008776, 2007.

Johnson, B. J., Oltmans, S. J., Vömel, H., Smit, H. G. J., Deshler, T., and Kröger, C.: Electrochemical concentration cell (ECC) ozonesonde pump efficiency measurements and tests on the sensitivity to ozone of buffered and unbuffered ECC sensor cathode solutions, J. Geophys. Res., 107, 4393, doi:10.1029/2001JD000557, 2002.

Jones, A., Urban, J., Murtagh, D. P., Eriksson, P., Brohede, S., Haley, C., Degenstein, D., Bourassa, A., von Savigny, C., Sonkaew, T., Rozanov, A., Bovensmann, H., and Burrows, J.: Evolution of stratospheric ozone and water vapour time series studied with satellite measurements, Atmos. Chem. Phys., 9, 6055-6075, doi:10.5194/acp-9-6055-2009, 2009.

Komhyr, W. D.: Electrochemical concentration cells for gas analysis, Ann. Geophys., 25, 203-210, 1969, http://www.ann-geophys.net/25/203/1969/.

Krzyścin, J. W. and Rajewska-Wiech, B.: Trends in the ozone vertical distribution from the Umkehr observations at Belsk 19632007, Int. J. Remote Sens., 30, 3917-3926, 2009.

Kyrölä, E., Tamminen, J., Sofieva, V., Bertaux, J. L., Hauchecorne, A., Dalaudier, F., Fussen, D., Vanhellemont, F., Fanton d'Andon, O., Barrot, G., Guirlet, M., Mangin, A., Blanot, L., Fehr, T., Saavedra de Miguel, L., and Fraisse, R.: Retrieval of atmospheric parameters from GOMOS data, Atmos. Chem. Phys., 10, 1188111903, doi:10.5194/acp-10-11881-2010, 2010.

Li, J., Cunnold, D. M., Wang, H.-J., Yang, E.-S., and Newchurch, M. J.: A discussion of upper stratospheric ozone asymmetries and SAGE trends, J. Geophys. Res., 107(D23), 4705, doi:10.1029/2001JD001398, 2002.

Livesey, N. J., Read, W. G., Froidevaux, L., Waters, J. W., Santee, M. L., Pumphrey, H. C., Wu, D. L., Shippony, Z., and Jarnot, R. F.: The UARS Microwave Limb Sounder version 5 data set: Theory, characterization, and validation, J. Geophys. Res., 108(D13), 4378, doi:10.1029/2002JD002273, 2003.

Logan, J. A., Megretskaia, I. A., Miller, J., Tiao, G. C., Choi, D., Zhang, L., Stolarski, R. S., Labow, G. J., Hollandsworth, S.M., Bodeker, G. E., Claude, H., De Muer, D., Kerr, J. B., Tarasick, D. W., Oltmans, S. J., Johnson, B., Schmidlin, F., Staehelin, J., Viatte, P., and Uchino, O.: Trends in the vertical distribution of ozone: A comparison of two analyses of ozonesonde data, J. Geophys. Res., 104, 26373-26399, 1999.

McGee, T. J., Gross, M., Ferrare, R., Heaps, W., and Singh, U.: Raman dial measurements of stratospheric ozone in the presence of volcanic aerosols, Geophys. Res. Lett., 20(10), 955-958, 1993.

McLinden, C. A., Tegtmeier, S., and Fioletov, V.: Technical Note: A SAGE-corrected SBUV zonal-mean ozone data set, Atmos. Chem. Phys., 9, 7963-7972, doi:10.5194/acp-9-7963-2009, 2009.
Nardi, B., Gille, J. C., Barnett, J. J., Randall, C. E., Harvey, V. L., Waterfall, A., Reburn, W. J., Leblanc, T., McGee, T. J., Twigg, L. W., Thompson, A. M., GodinBeekmann, S., Bernath, P. F., Bojkov, B. R., Boone, C. D., Cavanaugh, C., Coffey, M. T., Craft, J., Craig, C., Dean, V., Eden, T. D., Francis, G., Froidevaux, L., Halvorson, C., Hannigan, J. W., Hepplewhite, C. L., Kinnison, D. E., Khosravi, R., Krinsky, C., Lambert, A., Lee, H., Loh, J., Massie, S. T., McDermid, I. S., Packman, D., Torpy, B., ValverdeCanossa, J., Walker, K. A., Whiteman, D. N., Witte, J. C., Young, G.: Initial validation of ozone measurements from the High Resolution Dynamics Limb Sounder, J. Geophys. Res., 113, D16S36, doi:10.1029/2007JD008837, 2008.

Nazaryan, H. and McCormick, M. P.: Comparisons of Stratospheric Aerosol and Gas Experiment (SAGE II) and Solar Backscatter Ultraviolet Instrument (SBUV/2) ozone profiles and trend estimates, J. Geophys. Res., 110, D17302, doi:10.1029/2004JD005483, 2005.

Nazaryan, H., McCormick, M. P., and Russell III, J. M.: Comparative analysis of SBUV/2 and HALOE ozone profiles and trends, J. Geophys. Res., 112, D10304, doi:10.1029/2006JD007367, 2007.

Newchurch, M., Bishop, L., Cunnold, D., Flynn, L. E., Godin, S., Frith, S. H., Hood, L., Miller, A. J., Oltmans, S., Randel, W., Reinsel, G., Stolarski, R., Wang, R. Yang, E. S., and Zawodny, J. M.: Upper-stratospheric ozone trends 1979-1998, J. Geophys. Res., 105(D11), 14625-14636, 2000.

Newchurch, M. J., Yang, E.-S., Cunnold, D. M., Reinsel, G. C., and Zawodny, J. M.: Evidence for slowdown in stratospheric ozone loss: First stage of ozone recovery, J. Geophys. Res., 108(D16), 4507, doi:10.1029/2003JD003471, 2003.

Newman, P. A., Nash, E. R., Kawa, S. R., Montzka, S. A., and Schauffler, S. M.: When will the Antarctic ozone hole recover?, Geophys. Res. Lett., 33, L12814, doi:10.1029/2005GL025232, 2006.

Petropavlovskikh, I., Ahn, C., Bhartia, P. K., and Flynn, L. E.: Comparison and covalidation of ozone anomalies and variability observed in SBUV(/2) and Umkehr northern midlatitude ozone profile estimates, Geophys. Res. Lett., 32, L06805, doi:10.1029/2004GL022002, 2005a.

Petropavlovskikh, I., Bhartia, P. K., and DeLuisi J.: New Umkehr ozone profile retrieval algorithm optimized for climatological studies, Geophys. Res. Lett., 32, L16808, doi:10.1029/2005GL023323, 2005b.

Petropavlovskikh, I., Evans, R., McConville, G., Miyagawa, K., and Oltmans, S.: Effect of the out-of-band stray light on the retrieval of the Umkehr Dobson ozone profiles, Int. J. of Remote Sens., 30, 6461-6482, doi:10.1080/01431160902865806, 2009.

Press, W. H., Flannery, B. P., Teukolsky, S. A., and Vetterling, W. T.: Numerical recipes, Cambridge University Press, Cambridge, UK, 504-508, 1989.

Randel, W. J., Stolarski, R. S., Cunnold, D. M., Logan, J. A., Newchurch, M. J., and Zawodny, J. M.: Trends in the vertical distribution of ozone, Science, 285, 1689-1692, 1999.

Reinsel, G. C., Weatherhead, E. C., Tiao, G. C., Miller, A. J., Nagatani, R. M., Wuebbles, D. J., and Flynn, L. E.: On detection of turnaround and recovery in trend for ozone, J. Geophys. Res., 107(D10), 4078, doi:10.1029/2001JD000500, 2002.

Remsberg, E. E.: Trends and solar cycle effects in temperature versus altitude from the Halogen Occultation Experiment for 
the mesosphere and upper stratosphere, J. Geophys. Res., 114, D12303, doi:10.1029/2009JD011897, 2009.

Russell, J. III., Gordley, L. L., Park, J. H., Drayson, S. R., Hesketh, W. D., Cicerone, R. J., Tuck, A. F., Frederick, J. E., Harries, J. E., and Crutzen, P. J.: The Halogen Occultation Experiment, J. Geophys. Res., 98(D6), 10777-10797, 1993.

Smit, H. G. J., Straeter, W., Johnson, B. J., Oltmans, S. J., Davies, J., Tarasick, D. W., Hoegger, B., Stubi, R., Schmidlin, F. J., Northam, T., Thompson, A. M., Witte, J. C., Boyd, I, and Posny, F.: Assessment of the performance of ECC ozonesondes under quasi flight conditions in the environmental simulation chamber: Insights from the Juelich Ozone Sonde Intercomparison Experiment (JOSIE), J. Geophys. Res., 112, D19306, doi:10.1029/2006JD007308, 2007.

Steinbrecht, W., Claude, H., Schönenborn, F., McDermid, I. S., Godin, S., Song, T., Swart, D. P. J., Meijer, Y. J., Bodeker, G. E., Connor, B. J., Kämpfer, N., Hocke, K., Calisesi, Y., Schneider, N., de la Noë, J., Parrish, A. D., Boyd, I. S., Brühl, C., Steil, B., Giorgetta, M. A., Manzini, E., Thomason, L. W., Zawodny, J. M., McCormick, M. P., Russell III, J. M., Bhartia, P. K., Stolarski, R. S., and Hollandsworth-Frith, S. M.: Long-term evolution of upper stratospheric ozone at selected stations of the Network for the Detection of Stratospheric Change (NDSC), J. Geophys. Res., 111, D10308, doi:10.1029/2005JD006454, 2006.

Steinbrecht, W., Claude, H., Schönenborn, F., McDermid, I. S., Leblanc, T., Godin-Beekmann, S., Keckhut, P., Hauchecorne, A., Van Gijsel, J. A. E., Swart, D. P. J., Bodeker,G. E., Parrish, A., Boyd, I. S., Kämpfer, N., Hocke, K., Stolarski, R. S., Frith, S. M., Thomason, L. W., Remsberg, E. E., Von Savigny, C., Rozanov, A., and Burrows, J. P.: Ozone and temperature trends in the upper stratosphere at five stations of the Network for the Detection of Atmospheric Composition Change, Int. J. Remote Sens., 30, 3875-3886, doi:10.1080/01431160902821841, 2009.

Stratospheric Processes and Their Role in Climate (SPARC): Assessment of Trends in the Vertical Distribution of Ozone, SPARC Report 1, edited by: Harris, N., Hudson, R., and Phillips, C., WMO-Ozone Research and Monitoring Project Report No. 43, 1998.

Stratospheric Processes and Their Role in Climate (SPARC): SPARC Intercomparison of Middle Atmosphere Climatologies, SPARC Report 3, edited by: Randel, W., Chanin, M.-L., and Michaut, C., WMO/TD-No. 1142, 2002.

Stübi, R., Levrat, G., Hoegger, B., Viatte, P., Staehelin, J., and Schmidlin, F. J.: In-flight comparison of Brewer-Mast and electrochemical concentration cell ozonesondes, J. Geophys. Res., 113, D13302, doi:10.1029/2007JD009091, 2008.
Tatarov, B., Nakane, H., Park, Ch. B., Sugimoto, N., and Matsui, I.: Lidar observation of long-term trends and variations of stratospheric ozone and temperature over Tsukuba, Japan, Int. J. Remote Sens., 30, 3951-3960, 2009.

Terao, Y. and Logan, J. A.: Consistency of time series and trends of stratospheric ozone as seen by ozonesonde, SAGE II, HALOE, and SBUV(/2), J. Geophys. Res., 112, D06310, doi:10.1029/2006JD007667, 2007.

Van Gijsel, J. A. E., Swart, D. P. J., Baray, J.-L., Claude, H., Fehr, T., Von Der Gathen, P., Godin-Beekmann, S., Hansen, G. H., Leblanc, T., McDermid, I. S.,Meijer, Y. J., Nakane, H., Quel, E. J., Steinbrecht, W., Strawbridge, K. B., Tatarov, B., and Wolfram, E. A.: Global validation of ENVISAT ozone profiles using lidar measurements, Int. J. Remote Sens., 30, 3987-3994, doi:10.1080/01431160902821825, 2009.

Vömel, H., Oltmans, S. J., Hasebe, F., Shiotani, M., Fujiwara, M., Nishi, N., Agama, M., Cornejo, J., Paredes, F., and Enriquez, $\mathrm{H}$ : Balloon-borne observations of water vapor and ozone in the tropical upper troposphere and lower stratosphere, J. Geophys. Res., 107, doi:10.1029/2001JD000707, 2002.

Wang, H. J., Cunnold, D. M., Thomason, L. W., Zawodny, J. M., and Bodeker, G. E.: Assessment of SAGE version 6.1 ozone data quality, J. Geophys. Res., 107, 4691, doi:10.1029/2002JD002418, 2002.

Wang, P. H., Cunnold, D. M., Trepte, C. R., Wang, H. J., Jing, P., Fishman, J., Brackett, V. G., Zawodney, J. M., and Bodeker, G. E.: Ozone variability in the midlatitude upper troposphere and lower stratosphere diagnosed from a monthly SAGE II climatology relative to the tropopause, J. Geophys. Res., 111, D21304, doi:10.1029/2005JD006108, 2006.

World Meteorological Organization (WMO): Scientific assessment of ozone depletion: 1991, Global Ozone Research and Monitoring Project-Report No. 25, Geneva, Switzerland, 1992.

World Meteorological Organization (WMO): Scientific assessment of ozone depletion: 2006, Global Ozone Research and Monitoring Project-Report No. 50, 572 pp., Geneva, Switzerland, 2007.

Yang, E.-S., Cunnold, D. M., Salawitch, R. J., McCormick, M. P., Russell III, J., Zawodny, J. M., Oltmans, S., and Newchurch, M. J.: Attribution of recovery in lower-stratospheric ozone, J. Geophys. Res., 111, D17309, doi:10.1029/2005JD006371, 2006. 